Atmos. Chem. Phys., 13, 10659-10675, 2013

www.atmos-chem-phys.net/13/10659/2013/

doi:10.5194/acp-13-10659-2013

(c) Author(s) 2013. CC Attribution 3.0 License.

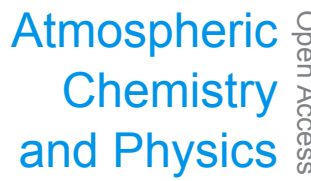

\title{
A global tropospheric ozone climatology from trajectory-mapped ozone soundings
}

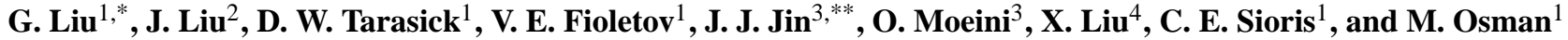 \\ ${ }^{1}$ Air Quality Research Division, Environment Canada, 4905 Dufferin Street, Downsview, ON M3H 5T4, Canada \\ ${ }^{2}$ Department of Geography and Program in Planning, University of Toronto, 100 St. George Street, Toronto, ON \\ M5S 3G3, Canada \\ ${ }^{3}$ Department of Earth and Space Science and Engineering, York University, Toronto, ON M3J 1P3, Canada \\ ${ }^{4}$ Harvard-Smithsonian Center for Astrophysics, Cambridge, MA 21250, USA \\ *now at: Space Sciences Laboratory, University of California, Berkeley, CA, 94720, USA \\ *** now at: GESTAR, Universities Space Research Association, Greenbelt, MD 20771, USA
}

Correspondence to: D. W. Tarasick (david.tarasick@ec.gc.ca)

Received: 11 February 2013 - Published in Atmos. Chem. Phys. Discuss.: 2 May 2013

Revised: 12 September 2013 - Accepted: 27 September 2013 - Published: 4 November 2013

\begin{abstract}
A global three-dimensional (i.e. latitude, longitude, altitude) climatology of tropospheric ozone is derived from the ozone sounding record by trajectory mapping. Approximately 52000 ozonesonde profiles from more than 100 stations worldwide since 1965 are used. The small number of stations results in a sparse geographical distribution. Here, forward and backward trajectory calculations are performed for each sounding to map ozone measurements to a number of other locations, and so to fill in the spatial domain. This is possible because the lifetime of ozone in the troposphere is of the order of weeks. This physically based interpolation method offers obvious advantages over typical statistical interpolation methods. The trajectory-mapped ozone values show reasonable agreement, where they overlap, to the actual soundings, and the patterns produced separately by forward and backward trajectory calculations are similar. Major regional features of the tropospheric ozone distribution are clearly evident in the global maps. An interpolation algorithm based on spherical functions is further used for smoothing and to fill in remaining data gaps. The resulting three-dimensional global tropospheric ozone climatology facilitates visualization and comparison of different years, decades, and seasons, and offers some intriguing insights into the global variation of tropospheric ozone. It will be useful for climate and air quality model initialization and validation, and as an a priori climatology for satellite data retrievals. Further division of the climatology into decadal and
\end{abstract}

annual averages can provide a global view of tropospheric ozone changes, although uncertainties with regard to the performance of older sonde types, as well as more recent variations in operating procedures, need to be taken into account.

\section{Introduction}

Ozone plays a major role in the chemical and radiative balance of the troposphere. Serving as a primary precursor to the formation of $\mathrm{OH}$ radicals, it controls the oxidizing capacity of the lower atmosphere, and thereby the capacity of the lower atmosphere to remove other pollutants. Ozone acts as an important infrared absorber (greenhouse gas), particularly in the upper troposphere, and because of multiple scattering, it is more effective in filtering surface UV-B than its small abundance in the troposphere (about $10 \%$ of the total column) would suggest. However, at ground level, ozone is responsible for significant damage to forests and crops, and is a principal factor in air quality, as it has adverse effects on human respiratory health (Bell et al., 2004; Lippmann, 1991; McConnell et al., 2002; Jerret et al., 2009).

Balloon-borne ozonesondes are the major source of tropospheric ozone information at high vertical resolution (about $100 \mathrm{~m}$ for modern sondes). However, ozone soundings are limited in spatial and temporal coverage. Ozonesondes are normally released from ground stations at fixed locations. 
Worldwide there are less than 100 stations that have routinely launched ozonesondes. These ozonesonde stations are generally located on continents and do not provide data over the oceans. Typically these stations launch sondes once a week, or at most 2-3 times a week, and as such temporal coverage is limited as well. Satellite observations of tropospheric ozone offer better spatial coverage, but are limited by the large stratospheric ozone burden that satellite instruments must look through (e.g. Bhartia, 2002). Recent instruments can provide some very limited vertical resolution, of about 6-10 km, in the troposphere (Worden et al., 2007a, b; X. Liu et al., 2005, 2010).

Several authors have developed ozone climatologies based entirely or partly on ozonesonde data (e.g. Logan, 1999; Fortuin and Kelder, 1998; Lamsal et al., 2004; McPeters et al., 1997, 2007; McPeters and Labow, 2012; Tilmes et al., 2012). A number of these have been used extensively in satellite ozone retrieval algorithms, which require an a priori estimate of the ozone profile (e.g. Bhartia, 2002), and as initial fields for climate models. With the exception of Tilmes et al. (2012), who considered aggregates of sonde data over a dozen large regions, all of these are zonally averaged (typically for $10^{\circ}$ latitude bands), and thus lack longitudinal structure. This lack of horizontal resolution is a major limitation, and is of course owing to the geographic sparseness of the ozone sounding data record.

However, as the lifetime of ozone in the troposphere is of the order of weeks, a measurement of ozone mixing ratio at one place and time also provides a good estimate of ozone mixing ratio in that same air parcel several hours or days before and after. It is therefore possible to employ a technique that has been used successfully in the stratosphere (Sutton et al., 1994; Newman and Schoeberl, 1995; Morris et al., 2000) and use forward and backward trajectory calculations for each sounding to map ozone measurements to a number of other locations, and so to fill in the spatial domain. In the troposphere, trajectories have larger errors than in the stratosphere (Stohl and Seibert, 1998), primarily because of the importance of vertical motion, which is difficult to model accurately, but also because of turbulence in the boundary layer. Nevertheless, trajectory-based domainfilling models have been used successfully to extend ozone climatologies based on MOZAIC aircraft data (Stohl et al., 2001), to reconstruct tropospheric water vapour fields (Pierrehumbert, 1998; Pierrehumbert and Roca, 1998; Dessler and Minschwaner, 2007), and to analyse small-scale variations in ozone mixing ratio observed by research aircraft (Methven et al., 2003).

This technique has recently been employed successfully with tropospheric ozone profile data from the North American IONS ozonesonde intensive campaigns (Tarasick et al., 2010). Here we employ a similar technique to the global ozonesonde data set, using the entire World Ozone and Ultraviolet Radiation Data Centre (WOUDC) record, to produce an improved three-dimensional (latitude, longitude, altitude) tropospheric ozone climatology for the globe.

\section{Ozonesonde data}

All data employed in this study were obtained from the World Ozone and Ultraviolet Radiation Data Centre (WOUDC) (http://www.woudc.org/) from 116 ozonesonde stations worldwide. Their data spans are summarized in Table 1 . The number of ozonesonde profiles available from different stations ranges from one to several thousand. Most of these stations are located in North America and Europe. There are only a few stations in Japan and along the east coast of China, giving somewhat poor coverage over Asia.

Most of the profiles are from the electrochemical concentration cell (ECC)-type ozonesonde, which was introduced in the early 1970s and adopted by the majority of stations in the global network by the early 1980s. Virtually all the data in the most recent decade are from ECC sondes. The remainder are from Brewer-Mast (BM) sondes (currently still in use at one site), the Japanese KC96 sonde, and the Indian sonde. Prior to the early 1990s, three stations in Europe (Praha, Lindenberg, and Legionowo) flew the GDR sonde. The majority of the data before 1980 is from BM sondes or similar (both the GDR and Indian sondes are similar in design to the BM sonde). A small amount of data is available from carboniodine sondes (similar to the KC sondes) and from Regener sondes (which operated by the chemiluminescent reaction of ozone with luminol) from the early 1960s.

When properly prepared and handled, electrochemical concentration cell (ECC) ozonesondes have a precision of $3-5 \%(1 \sigma)$ and an absolute accuracy of about $10 \%$ in the troposphere (Smit et al., 2007; Kerr et al., 1994; Deshler et al., 2008; G. Liu et al., 2009). The ozone sensor response time $\left(e^{-1}\right)$ of about $25 \mathrm{~s}$ gives the sonde a vertical resolution of about $100 \mathrm{~m}$ for a typical balloon ascent rate of $4 \mathrm{~m} \mathrm{~s}^{-1}$ in the troposphere. Two types of ECC ozonesondes are in current use - the $2 \mathrm{Z}$ model manufactured by EnSci Corp. and the $6 \mathrm{~A}$ model manufactured by Science Pump, with minor differences in construction and some variation in recommended concentrations of the potassium iodide-sensing solution and of its phosphate buffer. The maximum variation in tropospheric response resulting from these differences is likely of the order of 2-3\% (Smit et al., 2007). Although in the past BM sondes have shown somewhat variable response in the troposphere depending on preparation (World Climate Research Programme, 1998; Kerr et al., 1994; Tarasick et al., 2002), recent intercomparisons show little bias in the troposphere and a precision of about $10 \%$ (Smit et al., 1996). In early intercomparisons BM sondes showed negative biases of as much as $20 \%$ (Attmannspacher and Dütsch, 1970; Hilsenrath et al., 1986). The Japanese KC series sondes show a precision of about $5 \%$, but a low bias in the troposphere of about $5 \%$ (Smit and Straeter, 2004; Fujimoto et 
Table 1. Ozonesonde stations used in this study and their respective data spans. $(\mathrm{BM}=\mathrm{Brewer}-\mathrm{Mast}$; KC $=\mathrm{Japanese} \mathrm{KC}$ series; $\mathrm{CI}=$ carbon-iodine).

\begin{tabular}{|c|c|c|c|c|c|c|c|c|}
\hline WMO ID & $\begin{array}{l}\text { Station } \\
\text { Name }\end{array}$ & $\begin{array}{r}\text { Station } \\
\text { Latitude }\end{array}$ & $\begin{array}{r}\text { Station } \\
\text { Longitude }\end{array}$ & $\begin{array}{r}\text { Altitude } \\
(\mathrm{m})\end{array}$ & $\begin{array}{l}\text { Sonde } \\
\text { Type }\end{array}$ & $\begin{array}{r}\text { Earliest } \\
\text { Data }\end{array}$ & $\begin{array}{r}\text { Latest } \\
\text { Data }\end{array}$ & $\begin{array}{r}\text { \# of } \\
\text { Profiles }\end{array}$ \\
\hline 18 & ALERT/ALERT GAW LAB & 82.49 & -62.42 & 127 & ECC & 1987 & 2008 & 1122 \\
\hline 21 & EDMONTON/STONY PLAIN & 53.55 & -114.10 & 766 & ECC & 1978 & 2008 & 1286 \\
\hline 76 & GOOSE BAY & 53.30 & -60.36 & 40 & ECC & 1980 & 2008 & 1280 \\
\hline 344 & HONG KONG OBSERVATORY & 22.31 & 114.17 & 66 & ECC & 2000 & 2008 & 361 \\
\hline 43 & LERWICK & 60.13 & -1.18 & 80 & ECC & 1992 & 2008 & 814 \\
\hline 174 & LINDENBERG & 52.21 & 14.12 & 112 & ECC & 1992 & 2008 & 895 \\
\hline 233 & MARAMBIO & -64.23 & -56.62 & 196 & ECC & 1988 & 2008 & 673 \\
\hline 458 & YARMOUTH & 43.87 & -66.10 & 9 & ECC & 2003 & 2008 & 231 \\
\hline 316 & DE BILT & 52.10 & 5.18 & 4 & ECC & 1992 & 2008 & 860 \\
\hline 29 & MACQUARIE ISLAND & -54.50 & 158.97 & 6 & ECC & 1994 & 2008 & 554 \\
\hline 308 & MADRID / BARAJAS & 40.46 & -3.65 & 650 & ECC & 1994 & 2008 & 526 \\
\hline 323 & NEUMAYER & -70.65 & -8.25 & 42 & ECC & 1992 & 2008 & 1258 \\
\hline 107 & WALLOPS ISLAND & 37.90 & -75.48 & 13 & ECC & 1970 & 2008 & 1636 \\
\hline 156 & PAYERNE & 46.49 & 6.57 & 491 & ECC & 2002 & 2008 & 984 \\
\hline 348 & ANKARA & 39.95 & 32.88 & 896 & ECC & 1994 & 2008 & 278 \\
\hline 338 & BRATTS LAKE (REGINA) & 50.21 & -104.71 & 592 & ECC & 2003 & 2008 & 271 \\
\hline 457 & KELOWNA & 49.93 & -119.40 & 456 & ECC & 2003 & 2008 & 281 \\
\hline 24 & RESOLUTE & 74.72 & -94.98 & 40 & ECC & 1978 & 2008 & 1101 \\
\hline 53 & UCCLE & 50.80 & 4.35 & 100 & ECC & 1997 & 2008 & 1740 \\
\hline 318 & VALENTIA OBSERVATORY & 51.93 & -10.25 & 14 & ECC & 1994 & 2008 & 412 \\
\hline 437 & WATUKOSEK (JAVA) & -7.57 & 112.65 & 50 & ECC & 1999 & 2008 & 267 \\
\hline 109 & HILO & 19.57 & -155.05 & 11 & ECC & 1982 & 2008 & 1074 \\
\hline 466 & MAXARANGUAPE (SHADOZ-NATAL) & -5.45 & -35.33 & 32 & ECC & 2002 & 2008 & 293 \\
\hline 191 & SAMOA & -14.25 & -170.56 & 82 & ECC & 1995 & 2008 & 493 \\
\hline 436 & LA REUNION ISLAND & -20.99 & 55.48 & 68 & ECC & 1998 & 2008 & 282 \\
\hline 256 & LAUDER & -45.03 & 169.68 & 370 & ECC & 1986 & 2008 & 1384 \\
\hline 494 & ALAJUELA & 9.98 & -84.21 & 899 & ECC & 2007 & 2008 & 88 \\
\hline 394 & BROADMEADOWS & -37.69 & 144.95 & 108 & ECC & 1999 & 2008 & 433 \\
\hline 435 & PARAMARIBO & 5.81 & -55.21 & 23 & ECC & 1999 & 2008 & 437 \\
\hline 443 & SEPANG AIRPORT & 2.73 & 101.70 & 17 & ECC & 1998 & 2008 & 322 \\
\hline 77 & CHURCHILL & 58.75 & -94.07 & 35 & ECC & 1978 & 2008 & 1193 \\
\hline 450 & DAVIS & -68.58 & 77.97 & 16 & ECC & 2003 & 2008 & 135 \\
\hline 339 & USHUAIA & -54.85 & -68.31 & 15 & ECC & 2008 & 2008 & 30 \\
\hline 315 & EUREKA/EUREKA LAB & 80.04 & -86.18 & 310 & ECC & 1992 & 2008 & 1117 \\
\hline 190 & NAHA & 26.20 & 127.68 & 27 & ECC & 2008 & 2008 & 3 \\
\hline 175 & NAIROBI & -1.27 & 36.80 & 1745 & ECC & 1996 & 2008 & 481 \\
\hline 456 & EGBERT & 44.23 & -79.78 & 253 & ECC & 2003 & 2008 & 221 \\
\hline 221 & LEGIONOWO & 52.40 & 20.97 & 96 & ECC & 1993 & 2008 & 937 \\
\hline 434 & SAN CRISTOBAL & -0.92 & -89.60 & 8 & ECC & 1998 & 2008 & 325 \\
\hline 328 & ASCENSION ISLAND & -7.98 & -14.42 & 91 & ECC & 1990 & 2008 & 556 \\
\hline 336 & ISFAHAN & 32.48 & 51.43 & 1550 & ECC & 1995 & 2008 & 120 \\
\hline 242 & PRAHA & 50.02 & 14.45 & 304 & ECC & 1992 & 2008 & 818 \\
\hline 418 & HUNTSVILLE & 34.72 & -86.64 & 196 & ECC & 1999 & 2007 & 575 \\
\hline 265 & IRENE & -25.91 & 28.21 & 1524 & ECC & 1990 & 2007 & 365 \\
\hline 477 & HEREDIA & 10.00 & -84.11 & 1176 & ECC & 2006 & 2006 & 69 \\
\hline 89 & NY ALESUND & 78.93 & 11.88 & 243 & ECC & 1990 & 2006 & 1711 \\
\hline 262 & SODANKYLA & 67.34 & 26.51 & 179 & ECC & 1988 & 2006 & 1381 \\
\hline 485 & TECAMEC (UNAM) & 19.33 & -99.18 & 2272 & ECC & 2006 & 2006 & 35 \\
\hline 361 & HOLTVILLE (CA) & 32.81 & -115.42 & -18 & ECC & 2006 & 2006 & 13 \\
\hline 484 & HOUSTON (TX) & 29.72 & -95.40 & 19 & ECC & 2004 & 2006 & 62 \\
\hline 480 & SABLE ISLAND & 43.93 & -60.02 & 4 & ECC & 2004 & 2006 & 61 \\
\hline 260 & TABLE MOUNTAIN (CA) & 34.40 & -117.70 & 2286 & ECC & 2006 & 2006 & 35 \\
\hline 445 & TRINIDAD HEAD & 40.80 & -124.16 & 55 & ECC & 1999 & 2006 & 197 \\
\hline 490 & VALPARAISO (IN) & 41.50 & -87.00 & 240 & ECC & 2006 & 2006 & 18 \\
\hline 483 & BARBADOS & 13.16 & -59.43 & 32 & ECC & 2006 & 2006 & 27 \\
\hline 487 & NARRAGANSETT & 41.49 & -71.42 & 21 & ECC & 2006 & 2006 & 44 \\
\hline 488 & PARADOX & 43.92 & -73.64 & 284 & ECC & 2006 & 2006 & 8 \\
\hline 420 & BELTSVILLE (MD) & 39.02 & -76.74 & 64 & ECC & 2006 & 2006 & 12 \\
\hline 482 & WALSINGHAM & 42.60 & -80.60 & 200 & ECC & 2006 & 2006 & 43 \\
\hline 489 & RICHLAND & 46.20 & -119.16 & 123 & ECC & 2006 & 2006 & 24 \\
\hline 448 & MALINDI & -2.99 & 40.19 & -6 & ECC & 1999 & 2006 & 87 \\
\hline 438 & SUVA (FIJI) & -18.13 & 178.32 & 6 & ECC & 1997 & 2005 & 255 \\
\hline 257 & VANSCOY & 52.12 & -107.17 & 510 & ECC & 1990 & 2004 & 57 \\
\hline 360 & PELLSTON (MI) & 45.56 & -84.67 & 238 & ECC & 2004 & 2004 & 38 \\
\hline 406 & SCORESBYSUND & 70.49 & -21.98 & 50 & ECC & 1989 & 2003 & 647 \\
\hline 460 & THULE & 76.53 & -68.74 & 57 & ECC & 1991 & 2003 & 249 \\
\hline 401 & SANTA CRUZ & 28.42 & -16.26 & 36 & ECC & 1996 & 2003 & 322 \\
\hline
\end{tabular}


Table 1. Continued.

\begin{tabular}{|c|c|c|c|c|c|c|c|c|}
\hline WMO ID & $\begin{array}{l}\text { Station } \\
\text { Name }\end{array}$ & $\begin{array}{c}\text { Station } \\
\text { Latitude }\end{array}$ & $\begin{array}{r}\text { Station } \\
\text { Longitude }\end{array}$ & $\begin{array}{r}\text { Altitude } \\
(\mathrm{m})\end{array}$ & $\begin{array}{l}\text { Sonde } \\
\text { Type }\end{array}$ & $\begin{array}{r}\text { Earliest } \\
\text { Data }\end{array}$ & $\begin{array}{r}\text { Latest } \\
\text { Data }\end{array}$ & $\begin{array}{r}\text { \# of } \\
\text { Profiles }\end{array}$ \\
\hline 95 & TAIPEI & 25.02 & 121.48 & 25 & ECC & 2000 & 2001 & 64 \\
\hline 444 & CHEJU & 33.50 & 126.50 & 300 & $\mathrm{ECC}$ & 2001 & 2001 & 13 \\
\hline 219 & NATAL & -5.87 & -35.20 & 32 & ECC & 1979 & 2000 & 219 \\
\hline 432 & PAPEETE (TAHITI) & -18.00 & -149.00 & 2 & ECC & 1995 & 1999 & 168 \\
\hline 439 & KAASHIDHOO & 5.00 & 73.50 & 1 & ECC & 1999 & 1999 & 54 \\
\hline 254 & LAVERTON & -37.87 & 144.75 & 21 & ECC & 1989 & 1999 & 275 \\
\hline 404 & JOKIOINEN & 60.81 & 23.50 & 103 & ECC & 1995 & 1998 & 99 \\
\hline 441 & EASTER ISLAND & -27.17 & -109.42 & 62 & $\mathrm{ECC}$ & 1995 & 1997 & 75 \\
\hline 40 & HAUTE PROVENCE & 43.93 & 5.70 & 674 & ECC & 1981 & 1997 & 61 \\
\hline 67 & BOULDER & 40.09 & -105.25 & 1689 & $\mathrm{ECC}$ & 1979 & 1996 & 556 \\
\hline 65 & TORONTO & 43.78 & -79.47 & 198 & ECC & 1978 & 1994 & 8 \\
\hline 297 & S.PIETRO CAPOFIUME & 44.65 & 11.62 & 11 & ECC & 1984 & 1993 & 98 \\
\hline 333 & PORTO NACIONAL & -10.80 & -48.40 & 240 & ECC & 1992 & 1992 & 15 \\
\hline 329 & BRAZZAVILLE & -4.28 & 15.25 & 314 & ECC & 1990 & 1992 & 82 \\
\hline 335 & ETOSHA PAN & -19.20 & 15.90 & 1100 & ECC & 1992 & 1992 & 16 \\
\hline 334 & CUIABA & -15.60 & -56.10 & 990 & $\mathrm{ECC}$ & 1992 & 1992 & 21 \\
\hline 303 & IQALUIT & 63.75 & -68.55 & 20 & ECC & 1991 & 1992 & 30 \\
\hline 88 & MIRNY & -66.55 & 93.00 & 30 & & 1989 & 1991 & 114 \\
\hline 280 & NOVOLASAREVSKAYA/FORSTER & -70.77 & 11.87 & 110 & & 1985 & 1991 & 393 \\
\hline 111 & AMUNDSEN-SCOTT (S Pole) & -89.98 & 0.00 & 2820 & & 1967 & 1987 & 212 \\
\hline 255 & AINSWORTH (AIRPORT) & 42.58 & -100.00 & 789 & ECC & 1986 & 1986 & 7 \\
\hline 228 & GIMLI & 50.63 & -97.05 & 228 & ECC & 1980 & 1985 & 31 \\
\hline 210 & PALESTINE & 31.80 & -95.72 & 121 & $\mathrm{ECC}$ & 1975 & 1985 & 150 \\
\hline 213 & EL ARENOSILLO & 37.10 & -6.73 & 41 & ECC & 1983 & 1983 & 15 \\
\hline 217 & POKER FLAT & 65.13 & -147.45 & 358 & $\mathrm{ECC}$ & 1979 & 1982 & 40 \\
\hline 198 & COLD LAKE & 54.78 & -110.05 & 702 & ECC & 1979 & 1981 & 59 \\
\hline 20 & CARIBOU & 46.87 & -68.03 & 192 & ECC & 1981 & 1981 & 1 \\
\hline 229 & ALBROOK & 8.98 & -79.55 & 66 & ECC & 1980 & 1980 & 20 \\
\hline 194 & YORKTON & 51.26 & -102.47 & 504 & ECC & 1978 & 1978 & 10 \\
\hline 203 & FT. SHERMAN & 9.33 & -79.98 & 57 & ECC & 1977 & 1977 & 16 \\
\hline 239 & SAN DIEGO & 32.76 & -117.19 & 73 & ECC & 1977 & 1977 & 2 \\
\hline 238 & DENVER & 39.77 & -104.88 & 1611 & ECC & 1977 & 1977 & 1 \\
\hline 237 & GREAT FALLS & 47.48 & -111.35 & 1118 & ECC & 1977 & 1977 & 4 \\
\hline 235 & LONG VIEW & 32.50 & -94.75 & 103 & $\mathrm{ECC}$ & 1976 & 1976 & 2 \\
\hline 236 & COOLIDGE FIELD & 17.28 & -61.78 & 10 & ECC & 1976 & 1976 & 7 \\
\hline 234 & SAN JUAN & 18.48 & -66.13 & 17 & ECC & 1976 & 1976 & 6 \\
\hline 231 & SPOKANE & 47.67 & -117.42 & 576 & ECC & 1976 & 1976 & 7 \\
\hline 224 & CHILCA & -12.50 & -76.80 & -1 & ECC & 1975 & 1975 & 3 \\
\hline 199 & BARROW & 71.32 & -156.64 & 11 & ECC & 1974 & 1974 & 3 \\
\hline 225 & KOUROU & 5.33 & -52.65 & 4 & $\mathrm{ECC}$ & 1974 & 1974 & 3 \\
\hline 227 & MCDONALD OBSERVATORY & 30.67 & -90.93 & 2081 & ECC & 1969 & 1969 & 6 \\
\hline 99 & HOHENPEISSENBERG & 47.80 & 11.02 & 975 & BM & 1966 & 2008 & 4362 \\
\hline 156 & PAYERNE & 46.49 & 6.57 & 491 & BM & 1968 & 2002 & 3979 \\
\hline 53 & UCCLE & 50.80 & 4.35 & 100 & BM & 1966 & 1997 & 3142 \\
\hline 254 & LAVERTON & -37.87 & 144.75 & 21 & $\mathrm{BM}$ & 1982 & 1990 & 134 \\
\hline 213 & EL ARENOSILLO & 37.10 & -6.73 & 41 & & 1977 & 1983 & 20 \\
\hline 197 & BISCARROSSE/SMS & 44.37 & -1.23 & 18 & BM & 1976 & 1983 & 359 \\
\hline 26 & ASPENDALE & -38.03 & 145.10 & 1 & BM & 1965 & 1982 & 757 \\
\hline 76 & GOOSE BAY & 53.30 & -60.36 & 40 & $\mathrm{BM}$ & 1969 & 1980 & 532 \\
\hline 38 & CAGLIARI/ELMAS & 39.25 & 9.05 & 4 & $\mathrm{BM}$ & 1968 & 1980 & 419 \\
\hline 24 & RESOLUTE & 74.72 & -94.98 & 40 & BM & 1966 & 1979 & 605 \\
\hline 77 & CHURCHILL & 58.75 & -94.07 & 35 & $\mathrm{BM}$ & 1973 & 1979 & 276 \\
\hline 21 & EDMONTON/STONY PLAIN & 53.55 & -114.10 & 766 & BM & 1970 & 1979 & 349 \\
\hline 65 & TORONTO & 43.78 & -79.47 & 198 & $\mathrm{BM}$ & 1976 & 1978 & 9 \\
\hline 198 & COLD LAKE & 54.78 & -110.05 & 702 & BM & 1977 & 1978 & 7 \\
\hline 210 & PALESTINE & 31.80 & -95.72 & 121 & BM & 1977 & 1977 & 13 \\
\hline 194 & YORKTON & 51.26 & -102.47 & 504 & $\mathrm{BM}$ & 1975 & 1977 & 62 \\
\hline 104 & BEDFORD & 42.45 & -71.27 & 80 & $\mathrm{BM}$ & 1969 & 1971 & 77 \\
\hline 157 & THALWIL & 46.82 & 8.46 & 515 & $\mathrm{BM}$ & 1966 & 1968 & 187 \\
\hline 67 & BOULDER & 40.09 & -105.25 & 1689 & $\mathrm{BM}$ & 1963 & 1966 & 493 \\
\hline 64 & STERLING (WASHINGTON) & 38.98 & -77.48 & 84 & BM & 1963 & 1966 & 21 \\
\hline 138 & CHRISTCHURCH & -43.48 & 172.55 & 34 & BM & 1965 & 1965 & 25 \\
\hline 101 & SYOWA & -69.00 & 39.58 & 22 & $\mathrm{KC}$ & 1966 & 2008 & 1341 \\
\hline 12 & SAPPORO & 43.06 & 141.33 & 19 & $\mathrm{KC}$ & 1969 & 2008 & 1039 \\
\hline 14 & TATENO / TSUKUBA & 36.06 & 140.10 & 31 & $\mathrm{KC}$ & 1968 & 2008 & 1339 \\
\hline 190 & NAHA & 26.20 & 127.68 & 27 & $\mathrm{KC}$ & 1989 & 2008 & 734 \\
\hline 7 & KAGOSHIMA & 31.58 & 130.57 & 158 & $\mathrm{KC}$ & 1969 & 2005 & 841 \\
\hline
\end{tabular}


Table 1. Continued.

\begin{tabular}{|c|c|c|c|c|c|c|c|c|}
\hline WMO ID & $\begin{array}{l}\text { Station } \\
\text { Name }\end{array}$ & $\begin{array}{r}\text { Station } \\
\text { Latitude }\end{array}$ & $\begin{array}{r}\text { Station } \\
\text { Longitude }\end{array}$ & $\begin{array}{r}\text { Altitude } \\
(\mathrm{m})\end{array}$ & $\begin{array}{l}\text { Sonde } \\
\text { Type }\end{array}$ & $\begin{array}{r}\text { Earliest } \\
\text { Data }\end{array}$ & $\begin{array}{r}\text { Latest } \\
\text { Data }\end{array}$ & $\begin{array}{r}\text { \# of } \\
\text { Profiles }\end{array}$ \\
\hline 437 & WATUKOSEK (JAVA) & -7.57 & 112.65 & 50 & $\mathrm{KC}$ & 1998 & 1999 & 28 \\
\hline 205 & THIRUVANANTHAPURAM & 8.48 & 76.97 & 60 & Indian & 1969 & 2008 & 226 \\
\hline 187 & PUNE & 18.55 & 73.86 & 559 & Indian & 1966 & 2008 & 284 \\
\hline 400 & MAITRI & -70.46 & 11.45 & 224 & Indian & 1994 & 2008 & 141 \\
\hline 10 & NEW DELHI & 28.49 & 77.16 & 248 & Indian & 1969 & 2007 & 265 \\
\hline 206 & BOMBAY & 19.12 & 72.85 & 145 & Indian & 1968 & 1969 & 7 \\
\hline 9 & MOUNT ABU & 24.60 & 72.70 & 1220 & Indian & 1965 & 1966 & 4 \\
\hline 221 & LEGIONOWO & 52.40 & 20.97 & 96 & GDR & 1979 & 1993 & 497 \\
\hline 174 & LINDENBERG & 52.21 & 14.12 & 112 & GDR & 1975 & 1992 & 1240 \\
\hline 132 & SOFIA & 42.82 & 23.38 & 588 & GDR & 1982 & 1991 & 239 \\
\hline 242 & PRAHA & 50.02 & 14.45 & 304 & GDR & 1979 & 1991 & 448 \\
\hline 181 & BERLIN/TEMPLEHOF & 52.47 & 13.43 & 50 & GDR & 1966 & 1973 & 350 \\
\hline 72 & BYRD & -80.03 & -119.52 & 1528 & CI & 1966 & 1966 & 11 \\
\hline 111 & AMUNDSEN-SCOTT (S POLE) & -89.98 & 0.00 & 2820 & $\mathrm{CI}$ & 1966 & 1966 & 8 \\
\hline 64 & STERLING (WASHINGTON) & 38.98 & -77.48 & 84 & $\mathrm{CI}$ & 1964 & 1966 & 41 \\
\hline 105 & FAIRBANKS (COLLEGE) & 64.82 & -147.87 & 138 & $\mathrm{CI}$ & 1965 & 1965 & 14 \\
\hline 108 & CANTON ISLAND & -2.76 & -171.70 & 3 & $\mathrm{CI}$ & 1965 & 1965 & 4 \\
\hline 53 & UCCLE & 50.80 & 4.35 & 100 & Regener & 1965 & 1966 & 14 \\
\hline 64 & STERLING (WASHINGTON) & 38.98 & -77.48 & 84 & Regener & 1962 & 1966 & 106 \\
\hline 111 & AMUNDSEN-SCOTT (S POLE) & -89.98 & 0.00 & 2820 & Regener & 1962 & 1966 & 103 \\
\hline 72 & BYRD & -80.03 & -119.52 & 1528 & Regener & 1963 & 1965 & 100 \\
\hline 109 & HILO & 19.57 & -155.05 & 11 & Regener & 1964 & 1965 & 17 \\
\hline 108 & CANTON ISLAND & -2.76 & -171.70 & 3 & Regener & 1965 & 1965 & 27 \\
\hline 105 & FAIRBANKS (COLLEGE) & 64.82 & -147.87 & 138 & Regener & 1964 & 1965 & 37 \\
\hline 149 & OVEJUYO (LA PAZ) & -16.52 & -68.03 & 3420 & Regener & 1965 & 1965 & 10 \\
\hline 131 & PUERTO MONTT & -41.45 & -72.83 & 5 & Regener & 1964 & 1965 & 7 \\
\hline 76 & GOOSE BAY & 53.30 & -60.36 & 40 & Regener & 1963 & 1963 & 49 \\
\hline 69 & HALLETT & -72.32 & 170.22 & 5 & Regener & 1962 & 1963 & 26 \\
\hline 163 & WILKES & -66.25 & 110.52 & 12 & Regener & 1963 & 1963 & 7 \\
\hline 137 & TOPEKA & 39.07 & -95.63 & 270 & Regener & 1963 & 1963 & 10 \\
\hline
\end{tabular}

al., 2004; Kerr et al., 1994; Deshler et al., 2007). This bias appears to have been fairly consistent throughout the history of these sondes (Attmannspacher and Dütsch, 1970, 1981), but, like other sonde types, precision was poorer in the early period. In recent decades the Indian sonde has shown a precision of about $20 \%$ (Kerr et al., 1994; Smit et al., 1996), with little bias, but in the period previous to this, precision was poorer and the sonde showed a positive bias in intercomparisons (Attmannspacher and Dütsch, 1970, 1981). The GDR sonde showed a negative bias in the lower troposphere of about $7 \%$ and a positive bias, also of about $7 \%$, in the upper troposphere in two intercomparisons (Attmannspacher and Dütsch, 1970, 1981); however when only sondes with modest correction factors are considered, they show a much larger negative bias of about $20 \%$ in the lower troposphere decreasing to about 5-10\% in the upper troposphere (Feister et al., 1985). During this earlier period both the Indian and the GDR sonde show significantly larger variability in tropospheric response than other sonde types. Regener sondes were used regularly for only a brief period in the 1960s, as they showed somewhat erratic response. Tropospheric response was also quite variable, with an average bias of about $-40 \%$ (Chatfield and Harrison, 1977; Hering and Dütsch, 1965).

No attempt has been made to correct for these biases, so the maps for the 1960s and the 1970s should be regarded as biased low. Data from the 1970s (Table 1) are primarily from Brewer-Mast sondes, which also seem to have been biased low in the troposphere, particularly at Canadian and Australian stations (Tarasick et al., 2002; Lehmann, 2005), but also probably in Europe (Attmannspacher and Dütsch, 1970, 1981; Hilsenrath et al., 1986). BM sondes show an increase in tropospheric response relative to ECC sondes between the 1970s and the early 1990s (Attmannspacher and Dütsch, 1970, 1981; Kerr et al., 1994; Smit et al., 2007). Improved preparation procedures for BM sondes (Attmannspacher and Dütsch, 1978; Claude et al., 1987; World Climate Research Programme, 1998) may have contributed to this, and there are indications that there have been some minor changes in sonde manufacture over the long period of record (World Climate Research Programme, 1998). ECC sondes have also changed since their introduction (there have been several models), and there is some evidence that they may have been biased high in the troposphere in the earlier period (Barnes et al., 1985; Hilsenrath et al., 1986), although the reasons for this are unclear. However, ECC data comprise less than $5 \%$ of WOUDC ozonesonde data in the pre-1980 period. BM and GDR data comprise the bulk ( $81 \%$ ) of WOUDC ozonesonde data in the 1970s, while in the 1980s this fraction is $56 \%$ (and $37 \%$ for ECC sondes). This shift, in addition to the increase in BM sonde response during the 1970s and 1980s implied by the intercomparison data, may therefore cause an 
apparent increase in tropospheric ozone. No attempt has been made to correct for this, but possible consequences are discussed below.

All ozonesonde data have been processed to $1 \mathrm{~km}$ altitude resolution. That is, ozone partial pressures are integrated and averaged for $1 \mathrm{~km}$ thick layers from sea level. Dividing by the average pressure in each layer gives values for average ozone mixing ratio. The altitude information for ozone is calculated using the hydrostatic relation from the pressure and temperature profiles measured by the coupled radiosonde. Ozone volume mixing ratio, which is treated as a conserved quantity following air parcel motions, can thus be calculated for each layer (altitude). The tropopause height was calculated for each profile according to the World Meteorological Organization (1992) criterion, that is, the lowest height at which the temperature lapse rate falls to $2{ }^{\circ} \mathrm{C} \mathrm{km}^{-1}$ or less, provided that the average lapse rate for $2 \mathrm{~km}$ above this height is also not more than $2{ }^{\circ} \mathrm{C} \mathrm{km}^{-1}$. Profiles without a defined tropopause were excluded. The layer containing the tropopause, as well as those above, was not used. No other data screening was employed; although comparison with a coincident total ozone measurement ("correction factor" screening) is often used as a measure of sonde data quality (e.g. Fioletov et al., 2006), it is not applicable to the tropospheric part of the profile, and would also reduce the number of available profiles. This was an important consideration given the relatively limited coverage of the data record. Data submitted to the WOUDC have already been processed and screened for quality by the station operator and can be expected to represent the station's best effort at accuracy. While some errors will undoubtedly escape detection, they are likely to be, at any rate, smaller than typical atmospheric variability (since they would otherwise be obvious), and therefore for the purpose of constructing this climatology, data with larger uncertainties are better than no data.

Correction factors, as the name suggests, have also been commonly used to scale sonde profiles to agree with a coincident total ozone measurement. There is evidence that this improves data quality (e.g. Kerr et al., 1994; Smit et al., 1996; Beekman et al., 1994, 1995; Fioletov et al., 2006) but also that it introduces additional uncertainty (Morris et al., 2013; Tarasick et al., 2005). Here too, there have been variations in practice between stations and over time. As for the larger issues discussed above, no attempt has been made to correct for these differences.

These practices are currently being re-evaluated and station data records homogenized under the Ozonesonde Data Quality Assessment activity of the SPARC/IGACO/IOC/NDAAC ${ }^{1}$ initiative on "Past Changes in the Vertical Distribution of Ozone". Future versions of the

\footnotetext{
${ }^{1}$ SPARC $=$ Stratosphere-troposphere Processes And their Role in Climate

$\mathrm{IOC}=$ International Ozone Commission

IGACO = Integrated Global Atmospheric Chemistry

Observations
}

climatology presented here may then use the re-evaluated data. The current version uses the data as they currently are found in the WOUDC.

\section{$3 \quad$ Trajectory mapping}

For each ozonesonde profile, at $1 \mathrm{~km}$ height intervals $(0.5 \mathrm{~km}$, $1.5 \mathrm{~km}$, etc.) forward and backward trajectories were calculated using version 4.9 of the HYSPLIT model (Draxler and Hess, 1997, 1998), developed by the NOAA Air Resources Laboratory (NOAA ARL). The meteorological input for the trajectory model was the global NOAA-NCEP/NCAR (National Centers for Environmental Prediction/National Center for Atmospheric Research) pressure level reanalysis data set. An air parcel was assumed to be released at each $1 \mathrm{~km}$ altitude (above sea level) from the ozonesonde station (the releasing time, latitude, and longitude were taken from the ozonesonde launch). Four days of both backward and forward trajectories were calculated for the air parcel movement, and the original $(1 \mathrm{~km}$ altitude resolution) ozone data were mapped to the locations calculated for every six hours along the forward and backward trajectory paths. In this way each original data value was mapped into 32 additional ozone mixing ratio values. The original and trajectory-mapped data were then binned at intervals of $5^{\circ}$ latitude and $5^{\circ}$ longitude, at each $1 \mathrm{~km}$ altitude, and averaged. This bin size corresponds to the typical ozone correlation length in the troposphere of about $500 \mathrm{~km}$ (G. Liu et al., 2009). Two different altitude coordinates were employed for this binning, and so two sets of maps were produced, one whose vertical coordinate is altitude above sea level, and the other altitude above ground level. Both sets of maps are presented with and without smoothing.

Figure 1 illustrates the improved spatial coverage if trajectory mapping is used. The plots shown are for ozone integrated between 0 and $1 \mathrm{~km}$ above the surface and for 5 to $6 \mathrm{~km}$ above sea level. Different ages of trajectories are indicated by different colours. Figure 1 demonstrates that the trajectory mapping greatly spreads out the ozone information along the trajectory paths, increasing the spatial domain to include most of the globe within 3-4 days. Coverage is excellent, especially above the planetary boundary layer (PBL).

The reliability of the information thus obtained depends upon the accuracy of the calculated trajectories, and also on the assumption that ozone chemistry can be neglected over a 4-day timescale. The latter assumption is generally valid, since the average lifetime of ozone is about 22 days in the troposphere (Stevenson et al., 2006), although it varies with latitude, altitude, and season. In particular, it is less in the boundary layer and in the tropics (von Kuhlmann et al., 2003; Roelofs and Lelieveld, 1997). Moreover, as is well known, in pollution plumes photochemistry can produce ozone on

NDACC $=$ Network for the Detection of Atmospheric Composition Change 
(a)

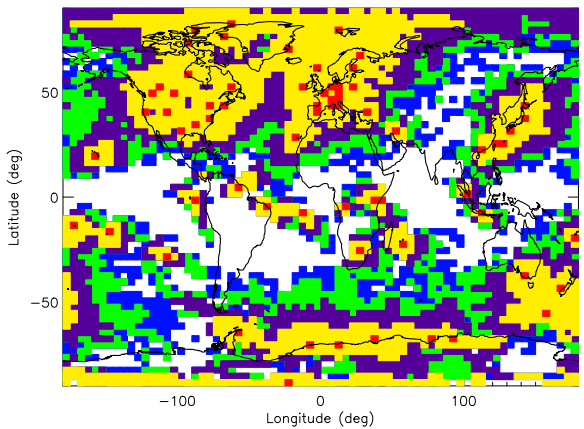

(b)

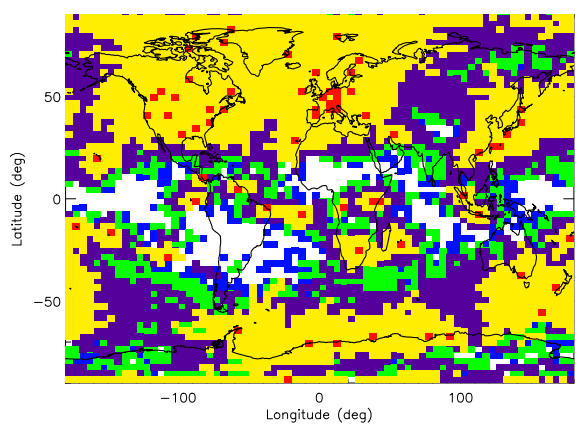

Fig. 1. Spatial coverage of 1-day (yellow squares), 2-day (purple squares), 3-day (green squares), and 4-day (blue squares) trajectories in April for (a) $0.5 \mathrm{~km}$ altitude above the surface (b) $5.5 \mathrm{~km}$ above sea level. The red squares denote the actual locations of the ozonesonde stations.

(a)
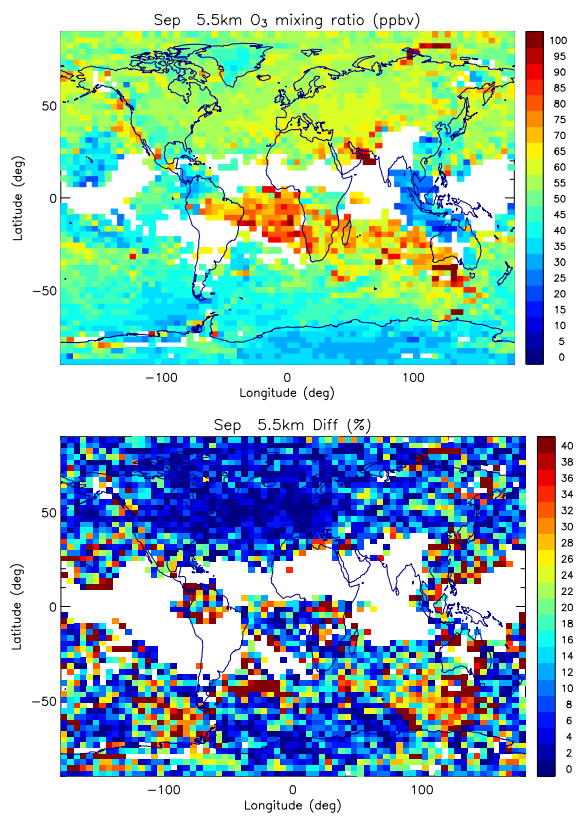

(b)

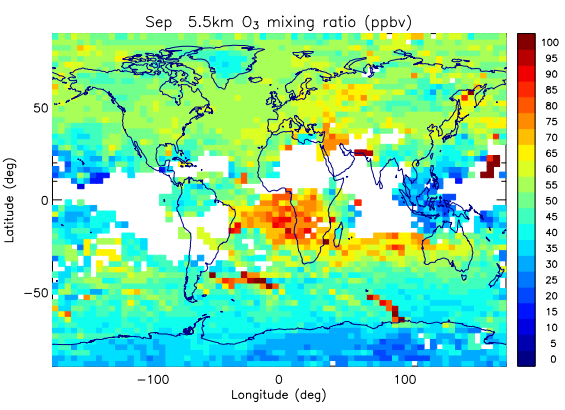

Fig. 2. Ozone distribution at $5.5 \mathrm{~km}$ from forward (a) and backward (b) trajectory mapping. (c) Difference between the two distributions in percent. Data from 1980 to 2008 are used.

timescales of a few days (e.g. Mao et al., 2006; Palmer et al., 2013), and lightning can produce ozone both directly (Minschwaner et al., 2008) and via lightning-generated NOx (e.g. Morris et al., 2010; Cooper et al., 2006), so this assumption can be violated in certain circumstances.

A number of studies have attempted to estimate, through several different methods, the accuracy of trajectories. Downey et al. (1990) estimated typical errors of $350 \mathrm{~km}$ for 4-day trajectories based on estimated wind errors. Stohl (1998) gave a comprehensive review of studies using balloons, material tracers, smoke plumes, and Saharan dust to evaluate trajectory errors, and quoted typical errors of $20 \%$ of the trajectory distance, or about $100-200 \mathrm{~km} \mathrm{day}^{-1}$ (with wide variation between studies). More recently Harris et al. (2005) evaluated trajectory model sensitivity to uncertainties in input meteorological fields and found uncertainties of 30-40\% of the horizontal trajectory distance, or 600-1000 km after four days, while Engström and Magnusson (2009), using an ensemble analysis method, found typical errors in the Northern Hemisphere of 350-400 km after three days, and $\sim 600 \mathrm{~km}$ after four days.

Sub-grid-scale convective processes are also not captured by HYSPLIT trajectories, which are calculated from gridded meteorological analysis fields. Convection is generally sporadic and randomly distributed, and its neglect does not likely represent an important bias to the average horizontal 

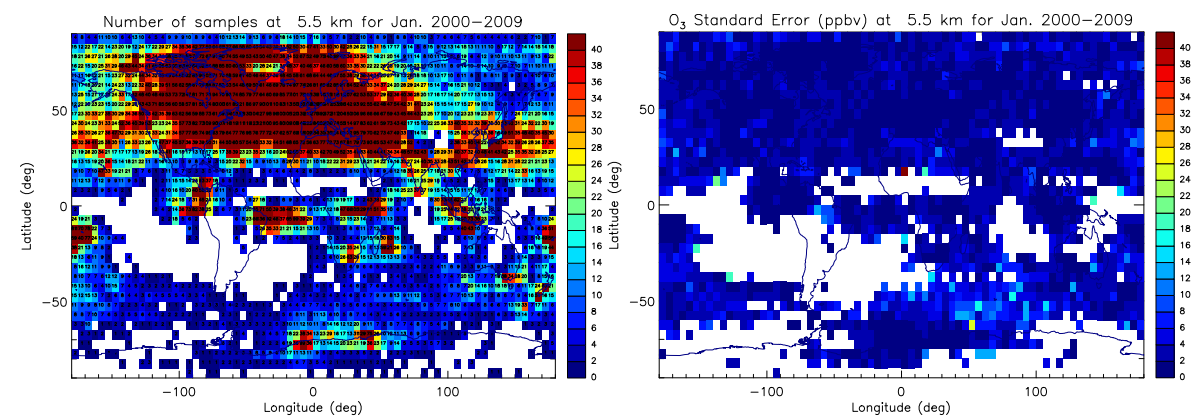

Fig. 3. Number of data values and the standard error of the mean for each pixel average in a decadal average map for January in the midtroposphere. The standard errors are generally of the order of a few ppbv (right figure), although where data density is low (left figure), they can be higher.
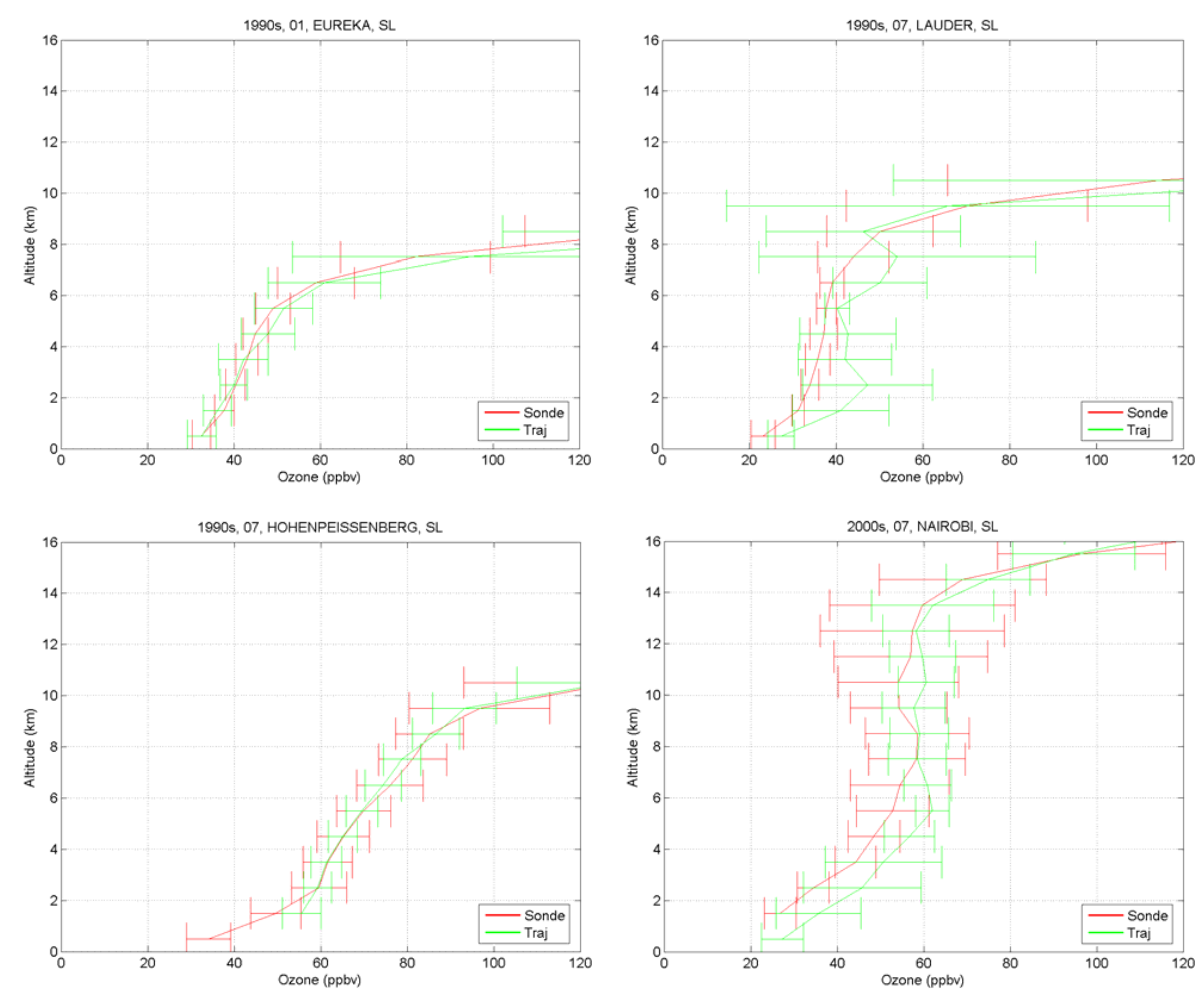

Fig. 4. Comparisons between the monthly $(01=$ January; $07=$ July $)$ averaged measured ozonesonde profiles and trajectory-mapped fields, for several sites. "Sonde" is the ensemble of measured profiles for that site; "Traj" is the profile generated from the mapping procedure when data from that site is omitted. Error bars indicate $2-\sigma$ confidence levels. The vertical coordinate is altitude from sea level (SL).

transport of ozone, except possibly in the Intertropical Convergence Zone. However, it is an important mechanism for the vertical mixing of ozone, and so acts to reduce vertical gradients; vertical gradients in this climatology might therefore be biased high, although not so much as to be evident in the validation comparisons. On a larger scale, the NCEP reanalysis apparently overestimates the convective precipitation in the tropics and in summer over Europe and North America (Stendel and Arpe, 1997), and this is presumably reflected as a bias in the vertical motion fields.
The estimates of $\sim 100-200 \mathrm{~km}$ day $^{-1}$ quoted above represent errors for individual trajectories in the troposphere. Errors in the final product should be much reduced by averaging of multiple trajectories, at least to the extent that single trajectory errors are random. However, in the PBL, complex dispersion and turbulence tends to render single trajectories less representative of the actual flow (Stohl and Seibert, 1998), and several authors suggest using an ensemble of trajectories (Merrill et al., 1985; Stohl, 1998). In the PBL, therefore, the averaging of ozone values from multiple 

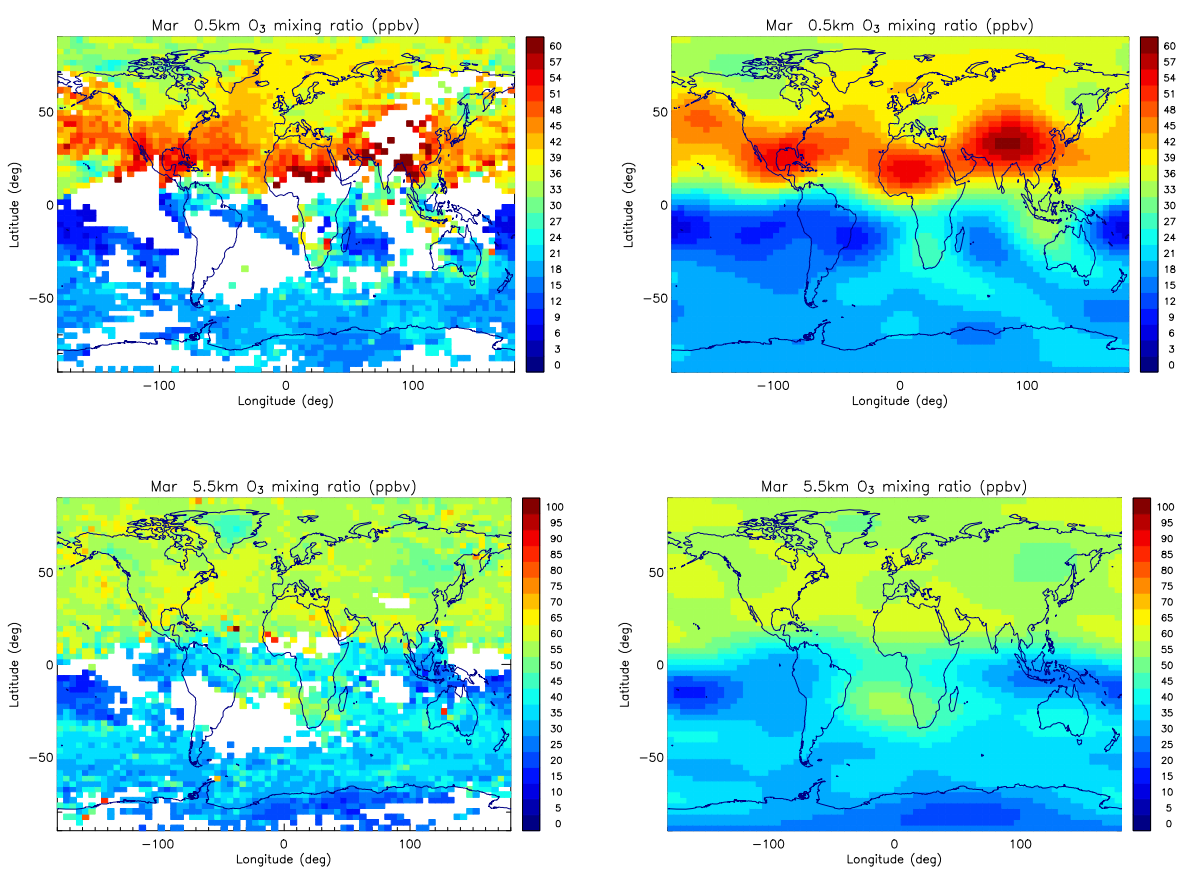

Fig. 5. Ozone maps at $0.5 \mathrm{~km}$ altitude above the surface and $5.5 \mathrm{~km}$ above sea level. Left-hand side: mapping; right-hand side: after smoothing and interpolation. Data from 1980 to 2008 are used.

trajectories in each pixel, as well as subsequent horizontal averaging (smoothing), will be particularly important for reducing trajectory errors. We nevertheless expect results for the lowest $(0-1 \mathrm{~km})$ layer to be less accurate than for higher levels. The ozone lifetime is also generally shorter near the surface, especially over the continents where dry deposition is a major loss process, affecting the validity of the assumption that chemistry can neglected.

Figure 2 assesses the differences between the ozone mapping produced using only backward and only forward trajectories. If ozone chemistry (i.e. local production in polluted regions) were a significant source of error, then one would expect to see differences between these maps. However, the ozone distribution patterns are in fact very similar. Differences have been calculated for all altitude levels, months, and latitude regions. Differences are most commonly $10 \%$ or less, and found to be less than $40 \%$ for almost all cases. As Fig. 2c illustrates, differences also show no distinct pattern except for some clustering in areas where the trajectories are longest, and therefore least reliable. As differences between the two distributions are comparable with the uncertainties of the mean values estimates and not systematic, it is reasonable to combine forward- and backward-mapped ozone values to produce an averaged ozone map.

The choice of September for these figures and April for those previous is arbitrary. The complete climatology comprises more than 15000 maps, and we have tried to show a variety of examples in the few figures in this paper.
Figure 3 shows the number of data values and the standard error of the mean for each pixel average in a typical decadal map. The standard errors are generally of the order of a few ppbv, although where data density is low, they can be higher. Note that this is for a $10 \mathrm{yr}$ average; for the $30 \mathrm{yr}$ averages, corresponding errors are smaller.

A revealing test of an interpolation model is to examine how it performs in areas where no data are available. Figure 4 compares ozone profiles produced via trajectory mapping with actual measured profiles for several ozonesonde stations. For this comparison the mapping uses ozonesonde measurements from all sites except the one being compared, and combines both forward and backward trajectories. Agreement is generally quite good in the free troposphere, with some larger differences in the lowest layer and near the tropopause. The differences near the surface might be expected since, as noted earlier, trajectories are probably less accurate in the PBL and photochemical production and loss of ozone is more rapid there. In the tropopause region ozone concentrations increase rapidly (and dynamic variability is large). Note that differences are shown in absolute units (ppbv).

Similar comparisons of mapped profiles with MOZAIC (aircraft) ozone profile data also show very good agreement (Tarasick et al., 2010). Maps for the $0-1 \mathrm{~km}$ layer over North America show reasonable agreement with maps of mean daily $1 \mathrm{~h}$ maximum surface ozone from the National Air Pollution Surveillance (NAPS) network Canadawide database and the US EPA Air Quality System (AQS) 

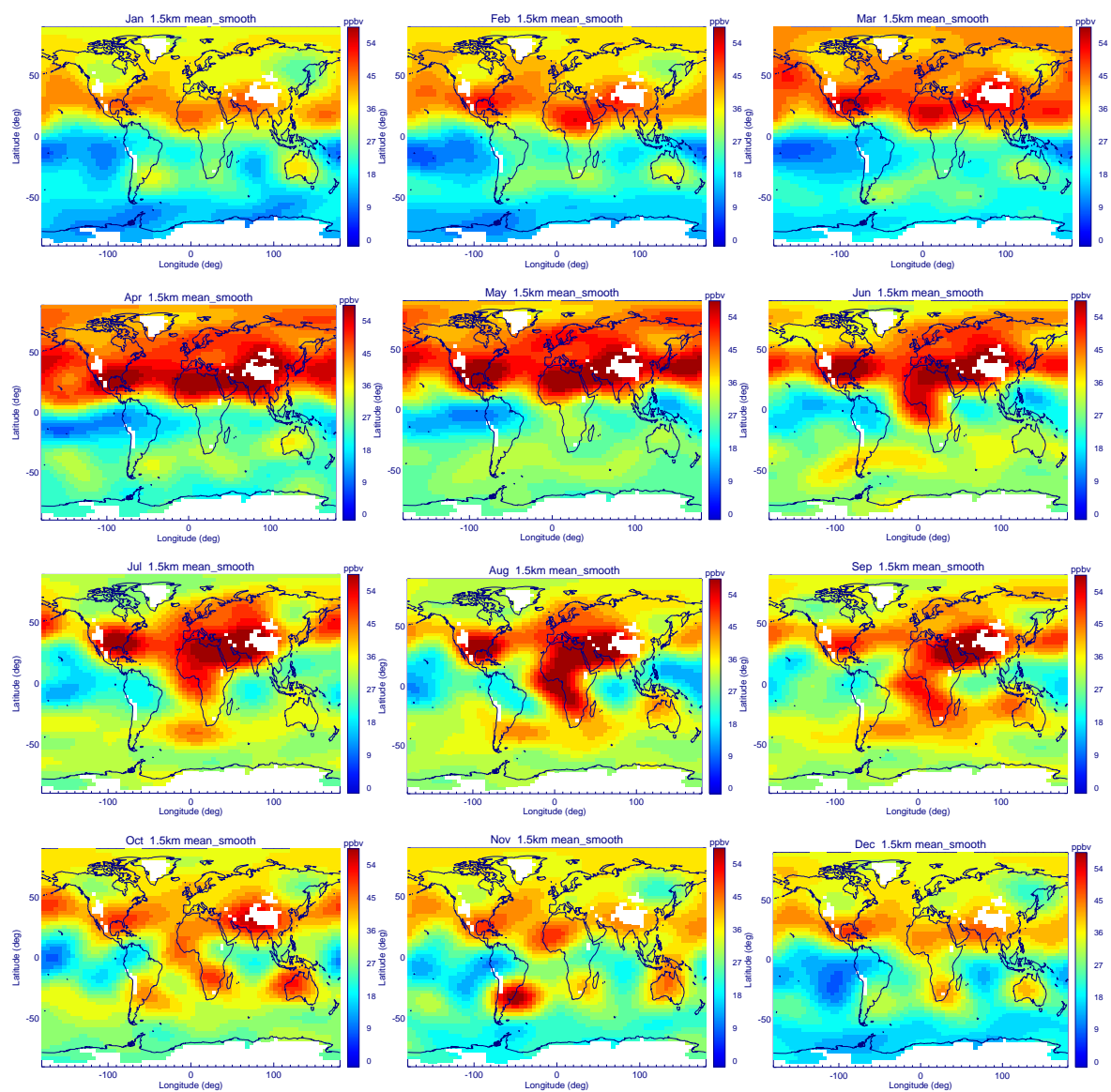

Fig. 6. Global ozone distributions at $1.5 \mathrm{~km}$ above sea level for all months. The trajectory-mapped results have been smoothed and further interpolated. Data from 1980 to 2008 are used.

database (1160 sites total), with correlation coefficients generally between 0.6 and 0.7 (Tarasick et al., 2010).

Figure 1 indicates that although the 4-day trajectory mapping greatly expands the spatial coverage of the ozonesonde measurements, there are still places where no ozone measurement is available. In order to fill in these data gaps and reduce small-scale "noise", the climatological average values obtained from the mapping are fitted to a linear combination of spherical functions. Figure 5 compares the ozone maps that are obtained from the trajectory mapping directly and following interpolation and smoothing by the spherical function interpolation algorithm. For a given altitude and month, the interpolated maps resemble the original maps, retaining broad features while reducing small-scale variability. In March, at the 0-1 km altitude level (above the surface), there are four strong ozone peaks in the northern extratropics. Three of these peaks are centred on the continents, while the remaining peak is over the Pacific Ocean. A similar pattern is seen at $5.5 \mathrm{~km}$ (above sea level), with weaker amplitudes and without the peak over the Himalayas (as this feature in the surface map is due to the high terrain). Similar features are seen in the tropospheric ozone column (TOC) fields produced from OMI/MLS observations (Ziemke et al., 2006; see http://acdb-ext.gsfc.nasa.gov/Data_services/cloud_slice/ gif/cl1.gif, although the TOC fields show low values over the Himalayas, the Andes, and the Rocky Mountains, since the atmospheric column is much less there due to the high terrain. Low values are of course also seen in the TOC fields calculated by vertically integrating the fields in this climatology (not shown).

The original and interpolated maps have been compared for all months and altitude levels (not shown) in order to evaluate the impact of the smoothing. Typical differences (for individual pixels) are similar to those found for the forward/backward trajectory comparisons: about $10-30 \%$ in the tropics and in the southern mid-latitude region, and about 10$20 \%$ in northern mid-latitudes.

Figure 6 shows the smoothed ozone fields at $1.5 \mathrm{~km}$ altitude above the surface for each month, while Fig. 7 shows the same fields at $4.5 \mathrm{~km}$ above sea level. Taken together, these again reproduce (as they should) features seen in the tropospheric ozone column (TOC) fields from OMI/MLS (with the exception of the low values over mountainous regions). Wellknown features such as the continental outflow from North 

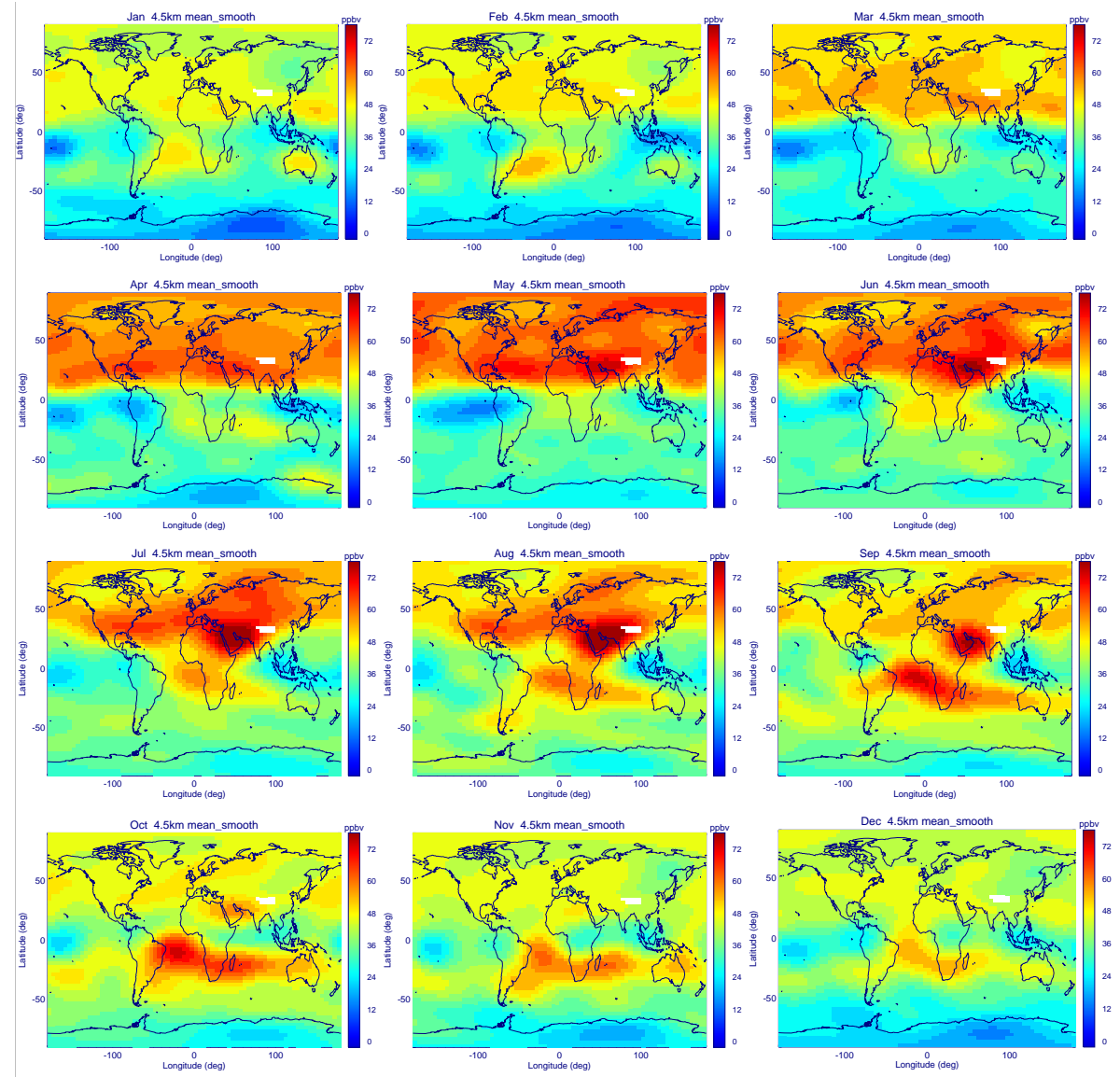

Fig. 7. As Fig. 6 but for $4.5 \mathrm{~km}$ altitude above sea level.

America, the summer ozone buildup over the Middle East (e.g. J. Liu et al., 2009), and biomass burning in the Southern Hemisphere, are clearly visible. The ozone production hotspots of the Middle East/Asia and the southern US are the most evident features, particularly in Fig. 6, but others - such as the continental outflow from the southeastern US, noted in satellite observations two decades ago (Fishman et al., 1990), and the influence of biomass burning in southern Africa and Indonesia - are also clearly visible. Interestingly, comparison of Figs. 6 and 7 shows that there are strong differences in the degree to which these emissions are lofted. Those from South America are much more evident at $4.5 \mathrm{~km}$ (Fig. 7) over the South Atlantic, especially in October, while burning in Australia's Northern Territory is much more evident nearer the surface (Fig. 6). Also, at $4.5 \mathrm{~km}$, the global ozone hotspot is the Middle East in summer, while northern and equatorial Africa show the highest ozone values nearer the surface. Both these features have been previously reported: the former has been observed in TES data (J. Liu et al., 2009), while the latter has been seen in MOZAIC data (Sauvage et al., 2005).

Figure 6 also shows the global variation in the seasonal cycle of tropospheric ozone. Ozone at $1-2 \mathrm{~km}$ is highest in the summer over the US, northern Africa, the Middle East, and much of Europe and southern Asia, as well as over equatorial Africa and the southern oceans. In contrast, over Canada, the northern oceans and everywhere in the Arctic and subArctic, ozone peaks in the March-April-May season, while over South America, southern Africa, and Australia the maximum occurs in the September-October-November season. This is quite consistent with recent model studies (Royal Society, 2008; see Box 5.2), although Fig. 6 shows little evidence of an equatorial maximum in the December-JanuaryFebruary season, as is predicted there.

Figures 8 and 9 show unsmoothed monthly maps at 45 and at $1-2 \mathrm{~km}$ for January and July for each decade since 1970. The lack of tropical data is evident in the preSHADOZ decades. Most notable, however, is the lack of evident change between decades after 1980. Some increase is apparent from the 1970s to the 1980s, but the patterns are remarkably similar in the following decades (although the patterns are smoother as the data density is greater). Figure 10 makes this more quantitative: a detailed comparison of the decadal data for all months, averaging over all $5^{\circ} \times 5^{\circ}$ pixels on the global map for which there is data for all four decades, produces several curves for the ratio of ozone concentration with altitude. The curves for the 1980s and 1990s indicate 

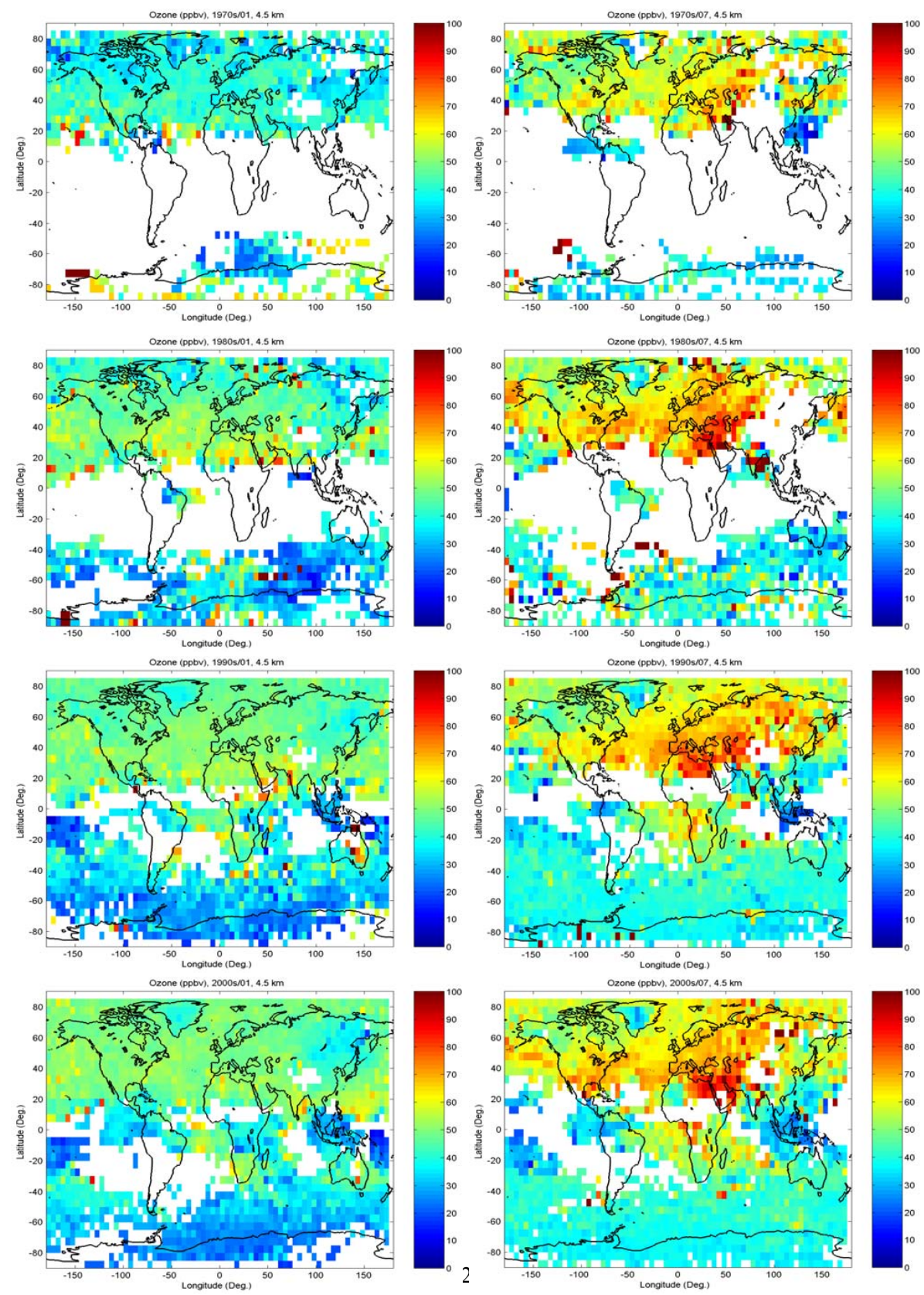

Fig. 8. Unsmoothed $\left(5^{\circ} \times 5^{\circ}\right.$ pixel averaged) maps at 4-5 km, for January (01) and July (07), for each decade since 1970 .

that over the area of complete sampling, average tropospheric ozone was about 1-3\% lower in the lowest $2 \mathrm{~km}$ of the troposphere in the 1980s and 1990s than in the 2000s, while above $2 \mathrm{~km}$ it was $1-4 \%$ lower in the 1990 s and $1-3 \%$ higher in the 1980s. This quasi-global average change is generally consistent with the results of the recent detailed trend study of Oltmans et al. (2012), but somewhat smaller than the trends found by Parrish et al. (2012) and Cooper et al. (2010).

The corresponding curve for the 1970s suggests a large increase below about $6-7 \mathrm{~km}$. However, as discussed above, recent comparisons show good agreement between ECC and BM sondes (e.g. Stubi et al., 2008), but past intercomparisons show a low bias for BM (and GDR) sondes. Such historical biases, and in combination with the migration of the global network to ECC sondes, may account at least in part for the post-1970 change. In fact, the curve for the 1970s closely resembles the corrections suggested for older BM data (Tarasick et al., 2002; Lehmann, 2005; Attmannspacher and Dütsch, 1970, 1981; Hilsenrath et al., 1986). 

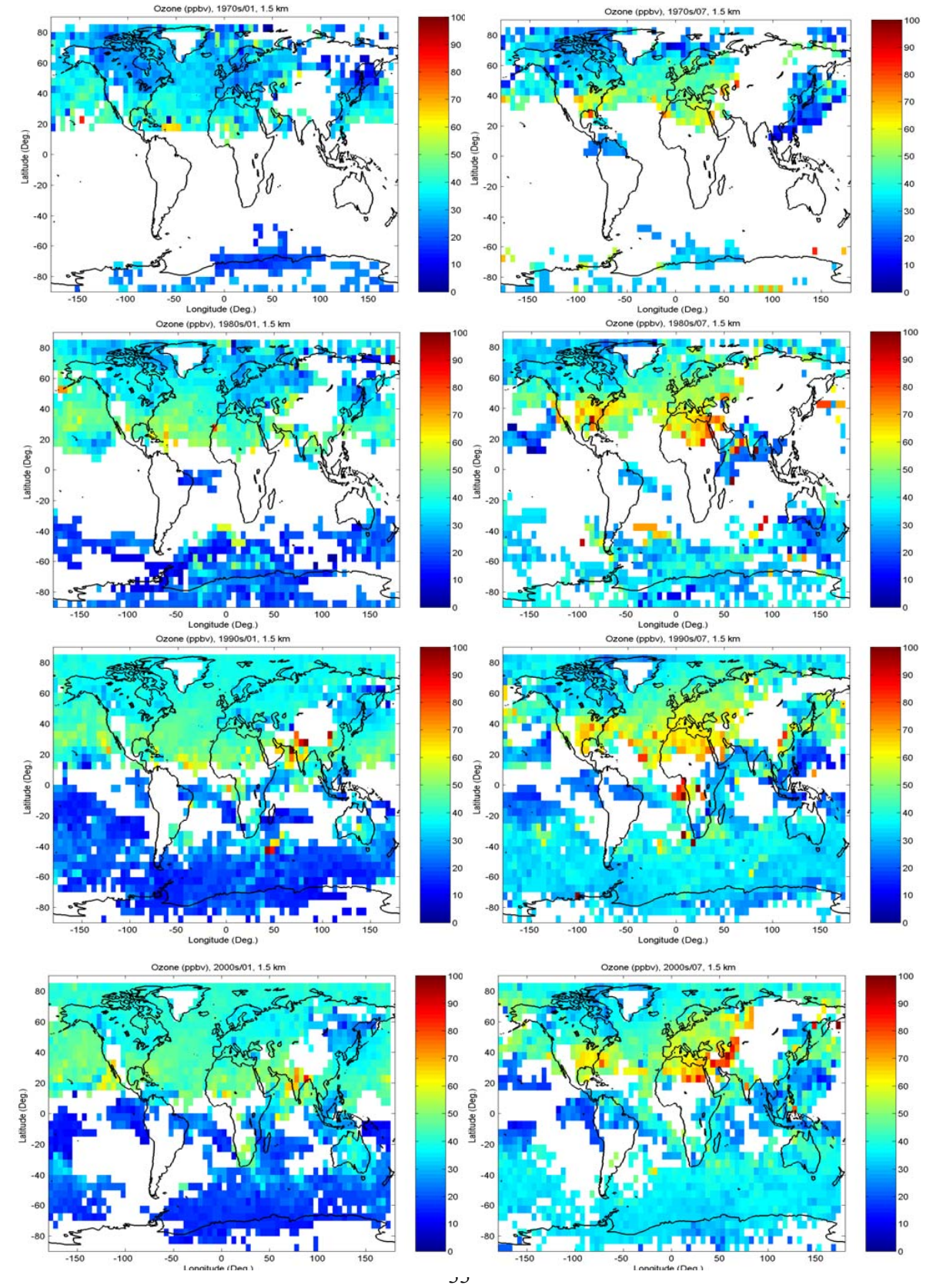

Fig. 9. Unsmoothed $\left(5^{\circ} \times 5^{\circ}\right.$ pixel averaged) maps at 1-2 km for January (01) and July (07) for each decade since 1970.

\section{Conclusions}

A spatial domain-filling technique using forward and backward trajectory calculations applied to the large sets of ozone soundings in the WOUDC has been shown to produce selfconsistent maps of the global ozone distribution for each month and altitude level in the troposphere from the 1960s to the 2000s. An interpolation method based on spherical functions is used for smoothing and to fill any remaining data gaps.
The mapped profiles agree well with sounding data excluded from the mapping, and maps produced using only backward and only forward trajectories also show good agreement (usually within $10 \%$, and almost always within $40 \%$ ). The resultant three-dimensional ozone fields show features that, where they have significant vertical extent, are also seen in tropospheric ozone column fields derived from OMI/MLS measurements.

The ozone climatology maps thus obtained exhibit many previously noted features of the seasonal distribution of ozone in the troposphere, while providing a wealth of detail 


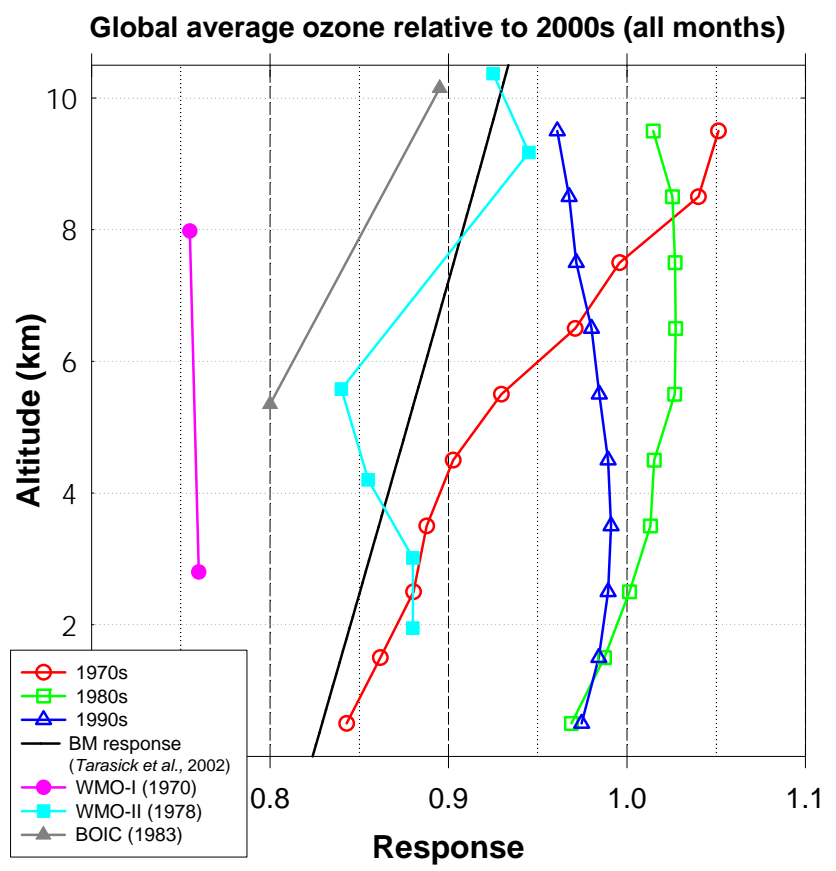

Fig. 10. Decadal average tropospheric ozone as a function of altitude, compared to the most recent decade. Averages are over all $5^{\circ} \times 5^{\circ}$ pixels on the global map for which there is data for all four decades. Also shown for reference are a quadratic best fit to BM response data from Tarasick et al. (2002), the average difference between BM and ECC response from ozonesonde intercomparisons in 1970 and 1978 (Attmannspacher and Dütsch, 1970, 1981), and the average response of BM sondes with respect to a reference UV photometer on the same balloon in 1983 (Hilsenrath et al., 1986).

about its horizontal and vertical variation. This detailed global picture offers some intriguing insights, such as the global variation in the seasonal cycle of tropospheric ozone, and a global view of tropospheric ozone changes over four decades.

It is expected that this climatology will be useful to other researchers as background information for (aircraft and model) process studies and for initialization and validation of models. It will also be useful for satellite data retrievals, which often require an accurate a priori profile of the vertical distribution of ozone in order to derive accurate column ozone amounts, to compensate for the lack of sensitivity to the lower troposphere, or to constrain profile retrieval algorithms. The TOC fields, obtained by integrating the climatology to the climatological average tropopause height, may also be used for validation of TOC retrievals.

Although not discussed here, by combining months, it is possible to produce maps of annual averages with similar data coverage. This technique offers the ability to map ozone near globally with high vertical resolution in the lower troposphere. Satellite remote sensing currently cannot provide such a product. These annual averages, or the seasonally resolved decadal averages, may be particularly valuable for validation of model studies of both recent tropospheric ozone changes (e.g. Jonson et al., 2006) and longer-term changes (e.g. Young et al., 2013).

Maps and data files are available from the authors and may also be downloaded at http://www.woudc.org.

Acknowledgements. The authors thank the many observers who, over many years, obtained the ozonesonde measurements used in this study. Their careful work is gratefully acknowledged. The global ozone sounding data were obtained from the World Ozone and Ultraviolet Radiation Data Centre (WOUDC, http://www.woudc.org) operated by Environment Canada, Toronto, Ontario, Canada, under the auspices of the World Meteorological Organization. We also gratefully acknowledge the the NOAA Air Resources Laboratory (ARL) for the provision of the trajectory model HYSPLIT (Hybrid Single Particle Lagrangian Integrated Trajectory Model) (http://www.arl.noaa.gov/ready.html), and the NOAA Physical Sciences Division for the NCEP/NCAR reanalysis data (http://www.esrl.noaa.gov/psd/data/reanalysis/reanalysis.shtml).

Edited by: A. Dastoor

\section{References}

Attmannspacher, A. and Dütsch, H. U.: International ozone sonde intercomparison at the Observatory Hohenpeissenberg, Ber. Dtsch. Wetterdienstes, 120, 1-85, 1970.

Attmannspacher, A. and Dütsch, H. U.: Second international ozone sonde intercomparison at the Observatory Hohenpeissenberg, Ber. Dtsch. Wetterdienstes, 157, 1-64, 1981.

Barnes, R. A., Bandy, A. R., and Torres, A. L.: Electrochemical concentration cell ozonesonde accuracy and precision, J. Geophys. Res., 90, 7881-7887, doi:10.1029/JD090iD05p07881, 1985.

Beekman, M., Ancellet, G., Mégie, G., Smit, H. G. J., and Kley, D.: Intercomparison campaign of vertical ozone profiles including electrochemical sondes of ECC and Brewer-Mast type and a ground-based UV-differential absorption lidar, J. Atmos. Chem., 19, 259-288, 1994.

Beekman, M., Ancellet, G., Martin, D., Abonnel, C., Duverneuil, G., Eideliman, F., Bessemoulin, P., Fritz, N., and Girard, E.: Intercomparison of tropospheric ozone profiles obtained by electrochemical sondes, a ground-based lidar and an airborne UVphotometer, Atmos. Environ., 29, 1027-1042, 1995.

Bell, M. L., McDermott, A., Zeger, S. L., Samet, J. M., and Dominici, F.: Ozone and short-term mortality in 95 US urban communities, 1987-2000, JAMA-J. Am. Med. Assoc., 292, 2372 2378, 2004.

Bhartia, P. K.: "OMI Algorithm Theoretical Basis Document: Volume II, OMI Ozone Products", ATBD-OMI-02, Version 2.0, August 2002.

Chatfield, R. and Harrison, H.: Tropospheric ozone: 1. Evidence for higher background values, J. Geophys. Res., 82, 5965-5968, doi:10.1029/JC082i037p05965, 1977.

Claude, H., Hartmannsgruber, R. and Köhler, U.: Measurement of Atmospheric Profiles using the Brewer-Mast Sonde, WMO Global Ozone Research and Monitoring Project, Report No. 17, 1987. 
Cooper, O. R., Stohl, A., Trainer, M., Thompson, A., Witte, J. C., Oltmans, S. J., Johnson, B. J., Merrill, J., Moody, J. L., Morris, G., Tarasick, D., Forbes, G., Nédélec, P., Fehsenfeld, F. C., Meagher, J., Newchurch, M. J., Schmidlin, F. J., Turquety, S., Crawford, J. H., Pickering, K. E., Cohen, R. C., Bertram, T., Wooldridge, P., and Brune, W. H.: Large upper tropospheric ozone enhancements above mid-latitude North America during summer: In situ evidence from the IONS and MOZAIC ozone monitoring network, J. Geophys. Res., 111, D24S05, doi:10.1029/2006JD007306, 2006.

Cooper, O. R., Parrish, D. D., Stohl, A., Trainer, M., Nédélec, P., Thouret, V.,. Cammas, J. P, Oltmans, S. J., Johnson, B. J., Tarasick, D., LeBlanc, T., McDermid, I. S., Jaffe, D., Gao, R., Stith, J., Ryerson, T., Aikin, K., Campos, T., and Weinheimer, A.: Increasing springtime ozone mixing ratios in the free troposphere over western North America, Nature, 463, 344-348, doi:10.1038/nature08708, 2010.

Deshler, T., Mercer, J., Smit, H. G. J., Stuebi, R., Levrat, G., Johnson, B. J., Oltmans, S. J., Kivi, R., Thompson, A. M., Witte, J., Davies, J., Schmidlin, F. J., Brothers, G., and Sasaki, T.: Atmospheric comparison of electrochemical cell ozonesondes from different manufacturers, and with different cathode solution strengths: The Balloon Experiment on Standards for Ozonesondes, J. Geophys. Res., 113, D04307, doi:10.1029/2007JD008975, 2008.

Dessler, A. E. and Minschwaner, K.: An analysis of the regulation of tropical tropospheric water vapor, J. Geophys. Res., 112, D10120, doi:10.1029/2006JD007683, 2007.

Downey, A., Jasper, J. D., Gras, J., and Whittlestone, S.: Lower tropospheric transport over the Southern Ocean, J. Atmos. Chem., 11, 43-68, doi:10.1007/BF00053667, 1990.

Draxler, R. R. and Hess, G. D.: An overview of the HYSPLIT_ 4 modelling system for trajectories, dispersion and deposition, Aust. Meteorol. Mag., 47, 295-308, 1998.

Draxler, R. R. and Hess, G. D.: Description of the HYSPLIT_ 4 modeling system, NOAA Technical Memorandum ERL ARL224, December, 24 pp., 1997.

Engström, A. and Magnusson, L.: Estimating trajectory uncertainties due to flow dependent errors in the atmospheric analysis, Atmos. Chem. Phys., 9, 8857-8867, doi:10.5194/acp-9-8857-2009, 2009.

Feister, U., Grasnick, K. H., and Peters, G.: Performance of the electrochemical ozone sonde OSR, Pure Appl. Geophys., 123, 422440, 1985.

Fioletov, V. E., Tarasick, D. W., and Petropavlovskikh, I.: Estimating ozone variability and instrument uncertainties from SBUV(/2), ozonesonde, Umkehr and SAGE II measurements. Part 1: Short-term variations, J. Geophys. Res., 111, D02305, doi:10.1029/2005JD006340, 2006.

Fishman, J., Watson, C. E., Larsen, J. C., and Logan, J. A.: Distribution of tropospheric ozone determined from satellite data, J. Geophys. Res., 95, 3599-3617, doi:10.1029/JD095iD04p03599, 1990.

Fortuin, J. and Kelder, H.: An ozone climatology based on ozonesonde and satellite measurements, J. Geophys. Res., 103, 31709-31733, 1998.

Fujimoto, T., Sato, T., Nagai, K., Nakano, T., Shitamichi, M., Kamata, Y., Miyauchi, S., Akagi, K., and Sasaki, T.: Further evaluation and improvements of Japanese KC-Ozonesonde through
JOSIE-2000, Proc. XX Quadrennial Ozone Symposium, 18 June 2004, Kos, Greece, International Ozone Commission, Athens, 540-541, 2004.

Harris, J. M., Draxler, R. R., and Oltmans, S. J.: Trajectory model sensitivity to differences in input data and vertical transport method, J. Geophys. Res., 110, D14109, doi:10.1029/2004JD005750, 2005.

Hering, W. S. and Dütsch, H. U.: Comparison of chemiluminescent and electrochemical ozonesonde observations, J. Geophys. Res., 70, 5483-5490, doi:10.1029/JZ070i022p05483, 1965.

Hilsenrath, E., Attmannspacher, W., Bass, A., Evans, W., Hagemeyer, R., Barnes, R. A., Komhyr, W., Mauersberger, K., Mentall, J., Proffitt, M., Robbins, D., Taylor, S., Torres A., and Weinstock, E.: Results from the balloon intercomparison campaign (BOIC), J. Geophys. Res., 91, 13137-13152, 1986.

Jerrett, M., Burnett, R. T., Pope III, C. A., Ito, K., Thurston, G., Krewski, D., Shi, Y., Calle, E., and Thun, M.: Long-Term Ozone Exposure and Mortality, N. Engl. J. Med., 360, 1085-1095, 2009.

Jonson, J. E., Simpson, D., Fagerli, H., and Solberg, S.: Can we explain the trends in European ozone levels?, Atmos. Chem. Phys., 6, 51-66, doi:10.5194/acp-6-51-2006, 2006.

Kerr, J. B., Fast, H., McElroy, C. T., Oltmans, S. J., Lathrop, J. A., Kyro, E., Paukkunen, A., Claude, H., Köhler, U., Sreedharan, C. R., Takao, T., and Tsukagoshi, Y.: The 1991 WMO international ozonesonde intercomparison at Vanscoy, Canada, Atmos.-Ocean, 32, 685-716, 1994.

Lamsal, L., Weber, M., Tellmann, S., and Burrows, J.: Ozone column classified climatology of ozone and temperature profiles based on ozonesonde and satellite data, J. Geophys. Res., 109, D20304, doi:10.1029/2004JD004680, 2004.

Lehmann, P.: An Estimate of the Vertical Ozone Profile Discrepancy between the Australian Brewer - Mast and Electrochemical Concentration Cell Ozonesondes, J. Atmos. Ocean. Tech., 22, 1864-1874, doi:10.1175/JTECH1821.1, 2005.

Lippmann, M.: Health-effects of tropospheric ozone, Envir. Sci. Tech., 25, 1954-1962, 1991.

Liu, G., Tarasick, D. W., Fioletov, V. E., Sioris, C. E., and Rochon, Y. J.: Ozone correlation lengths and measurement uncertainties from analysis of historical ozonesonde data in North America and Europe, J. Geophys. Res., 114, D04112, doi:10.1029/2008JD010576, 2009.

Liu, J. J., Jones, D. B. A., Worden, J. R., Noone, D., Parrington, M., and Kar, J.: Analysis of the summertime buildup of tropospheric ozone abundances over the Middle East and North Africa as observed by the Tropospheric Emission Spectrometer instrument, J. Geophys. Res., 114, D05304, doi:10.1029/2008JD010993, 2009.

Liu, X., Chance, K., Sioris, C. E., Spurr, R. J. D., Kurosu, T. P., Martin, R. V., and Newchurch, M. J.: Ozone profile and tropospheric ozone retrieval from the Global Ozone Monitoring Experiment: Algorithm description and validation, J. Geophys. Res., 110, D20307, doi:10.1029/2005JD006240, 2005.

Liu, X., Bhartia, P. K., Chance, K., Spurr, R. J. D., and Kurosu, T. P.: Ozone profile retrievals from the Ozone Monitoring Instrument, Atmos. Chem. Phys., 10, 2521-2537, doi:10.5194/acp-10-25212010, 2010.

Logan, J. A.: An analysis of ozonesonde data for the troposphere: Recommendations for testing 3-D models and development of a gridded climatology for tropospheric ozone, J. Geophys. Res, 104, 16115-16149, doi:10.1029/1998JD100096, 1999. 
Mao H., Talbot, R., Troop, D., Johnson, R., Businger, S., and Thompson, A. M.: Smart balloon observations over the North Atlantic: $\mathrm{O}_{3}$ data analysis and modeling, J. Geophys. Res., 111, D23S56, doi:10.1029/2005JD006507, 2006.

McConnell, R., Berhane, K., Gilliland, F., London, S. J., Islam, T., Gauderman, W. J., Avol, E., Margolis, H. G., and Peters, J. M.: Asthma in exercising children exposed to ozone: A cohort study, Lancet, 359, 386-391, 2002.

McPeters, R. D., Labow, G. J., and Johnson, B. J.: A satellitederived ozone climatology for balloonsonde estimation of total column ozone, J. Geophys. Res., 102, 8875-8885, 1997.

McPeters, R. D., Labow, G. J., and Logan, J. A.: Ozone climatological profiles for satellite retrieval algorithms, J. Geophys. Res., 112, D05308, doi:10.1029/2005JD006823, 2007.

McPeters, R. D. and Labow, G. J.: Climatology 2011: An MLS and sonde derived ozone climatology for satellite retrieval algorithms, J. Geophys. Res., 117, D10303, doi:10.1029/2011JD017006, 2012.

Merrill, J., Bleck, R., and Avila, L.: Modeling Atmospheric Transport to the Marshall Islands, J. Geophys. Res., 90, 12927-12936, 1985.

Methven, J., Arnold, S. R., O'Connor, F. M., Barjat, H., Dewey, K., Kent, J., and Brough, N.: Estimating photochemically produced ozone throughout a domain using flight data and a Lagrangian model, J. Geophys. Res., 108, 4271, doi:10.1029/2002JD002955, 2003.

Minschwaner, K., Kalnajs, L. E., Dubey, M. K., Avallone, L. M., Sawaengphokai, P. C., Edens, H. E., and Winn, W. P.: Observation of enhanced ozone in an electrically active storm over Socorro, NM: Implications for ozone production from corona discharges, J. Geophys. Res., 113, D17208, doi:10.1029/2007JD009500, 2008.

Morris, G. A, Gleason, J. F., Ziemke, J., and Schoeberl, M. R.: Trajectory mapping: A tool for validation of trace gas observations, J. Geophys. Res., 105, 17875-17894, 2000.

Morris, G. A., Thompson, A. M., Pickering, K. E., Chen, S., Bucsela, E. J., and Kucera, P. A.: Observations of ozone production in a dissipating tropical convective cell during TC4, Atmos. Chem. Phys., 10, 11189-11208, doi:10.5194/acp-10-11189-2010, 2010.

Morris, G. A., Labow, G., Akimoto, H., Takigawa, M., Fujiwara, M., Hasebe, F., Hirokawa, J., and Koide, T.: On the use of the correction factor with Japanese ozonesonde data, Atmos. Chem. Phys., 13, 1243-1260, doi:10.5194/acp-13-1243-2013, 2013.

Newman, P. A. and Schoeberl, M. R.: A reinterpretation of the data from the NASA Stratosphere-Troposphere Exchange Project, Geophys. Res. Lett., 22, 2501-2504, 1995.

Oltmans, S. J., Lefohn, A. S., Shadwick, D., Harris, J. M., Scheel, H. E., Galbally, I., Tarasick, D. W., Johnson, B. J., Brunke, E.G., Claude, H., Zeng, G., Nichol, S., Schmidlin, F., Davies, J., Cuevas, E., Redondas, A., Naoe, H., Nakano, T., and Kawasato, T.: Recent Tropospheric Ozone Changes - A Pattern Dominated by Slow or No Growth, Atmos. Environ., 67, 331-351, doi:10.1016/j.atmosenv.2012.10.057, 2012.

Palmer, P. I., Parrington, M., Lee, J. D., Lewis, A. C., Rickard, A. R., Bernath, P. F., Duck, T. J., Waugh, D. L., Tarasick, D. W., Andrews, S., Aruffo, E., Bailey, L. J., Barrett, E., Bauguitte, S. J.-B., Curry, K. R., Di Carlo, P., Chisholm, L., Dan, L., Forster, G., Franklin, J. E., Gibson, M. D., Griffin, D., Helmig, D., Hopkins, J. R., Hopper, J. T., Jenkin, M. E., Kindred, D., Kliever, J.,
Le Breton, M., Matthiesen, S., Maurice, M., Moller, S., Moore, D. P., Oram, D. E., O'Shea, S. J., Owen, R. C., Pagniello, C. M. L. S., Pawson, S., Percival, C. J., Pierce, J. R., Punjabi, S., Purvis, R. M., Remedios, J. J., Rotermund, K. M., Sakamoto, K. M., da Silva, A. M., Strawbridge, K. B., Strong, K., Taylor, J., Trigwell, R., Tereszchuk, K. A., Walker, K. A., Weaver, D., Whaley, C., and Young, J. C.: Quantifying the impact of BOReal forest fires on Tropospheric oxidants over the Atlantic using Aircraft and Satellites (BORTAS) experiment: design, execution and science overview, Atmos. Chem. Phys., 13, 6239-6261, doi:10.5194/acp-13-6239-2013, 2013.

Parrish, D. D., Law, K. S., Staehelin, J., Derwent, R., Cooper, O. R., Tanimoto, H., Volz-Thomas, A., Gilge, S., Scheel, H.-E., Steinbacher, M., and Chan, E.: Long-term changes in lower tropospheric baseline ozone concentrations at northern mid-latitudes, Atmos. Chem. Phys., 12, 11485-11504, doi:10.5194/acp-1211485-2012, 2012.

Pierrehumbert, R.: Lateral Mixing as a Source of Subtropical Water Vapor, Geophys. Res. Lett., 25, 151-154, 1998.

Pierrehumbert, R. and Roca, R.: Evidence for Control of Atlantic Subtropical Humidity by Large Scale Advection, Geophys. Res. Lett., 25, 4537-4540, 1998.

Roelofs, G.-J. and Lelieveld, J.: Model study of the influence of cross-tropopause $\mathrm{O}_{3}$ transports on tropospheric $\mathrm{O}_{3}$ levels, Tellus, B, 49, 38-55, 1997.

Royal Society: Ground-level ozone in the 21st century: future trends, impacts and policy implications, Science Policy Report 15/08, October 2008, RS1276, (http://royalsociety.org/policy/ publications/2008/ground-level-ozone/), 2008.

Sauvage, B., Thouret, V., Cammas, J.-P., Gheusi, F., Athier, G., and Nédélec, P.: Tropospheric ozone over Equatorial Africa: regional aspects from the MOZAIC data, Atmos. Chem. Phys., 5, 311335, doi:10.5194/acp-5-311-2005, 2005.

Smit, H. G. J. and Straeter, W.: JOSIE-2000, Jülich Ozone Sonde Intercomparison Experiment 2000, The 2000 WMO international intercomparison of operating procedures for ECC-ozonesondes at the environmental simulation facility at Jülich, WMO Global Atmosphere Watch report series, No. 158 (Technical Document No. 1225), World Meteorological Organization, Geneva, 2004.

Smit, H. G. J., Sträter, W., Helten, M., Kley, D., Ciupa, D., Claude, H. J., Köhler, U., Hoegger, B., Levrat, G., Johnson, B., Oltmans, S. J., Kerr, J. B., Tarasick, D. W., Davies, J., Shitamichi, M., Srivastav, S. K., and Vialle, C.: JOSIE: The 1996 WMO international intercomparison of ozonesondes under quasi-flight conditions in the environmental chamber at Jülich, in: Atmospheric Ozone: Proceedings of the Quadrennial $\mathrm{O}_{3}$, Symposium, l'Aquila, Italy, edited by: Bojkov, R. D. and Visconti, G., 971974, Parco Sci. e Tecnol. d'Abruzzo, Italy, 1996.

Smit, H. G. J., Straeter, W., Johnson, B., Oltmans, S., Davies, J., Tarasick, D. W., Hoegger, B., Stubi, R., Schmidlin, F., Northam, T., Thompson, A., Witte, J., Boyd, I., and Posny, F.: Assessment of the performance of ECC-ozonesondes under quasi-flight conditions in the environmental simulation chamber: Insights from the Juelich Ozone Sonde Intercomparison Experiment (JOSIE), J. Geophys Res., 112, D19306, doi:10.1029/2006JD007308, 2007.

Stendel, M. and Arpe, K.: Evaluation of the hydrological cycle in reanalyses and observations, Max-Planck-Institute for Meteorology, Report No. 228, 52 pp, available from Max-Planck-Institut 
für Meteorologie, Bundesstrasse 55, 20147 Hamburg, Germany, 1997.

Stevenson, D. S., Dentener, F. J., Schultz, M. G., Ellingsen, K., van Noije, T. P. C., Wild, O., Zeng, G., Amann, M., Atherton, C. S., Bell, N., Bergmann, D. J., Bey, I., Butler, T., Cofala, J., Collins, W. J., Derwent, R. G., Doherty, R. M., Drevet, J., Eskes, H. J., Fiore, A. M., Gauss, M., Hauglustaine, D. A., Horowitz, L. W., Isaksen, I. S. A., Krol, M. C., Lamarque, J.-F., Lawrence, M. G., Montanaro, V., Müller, J.-F., Pitari, G., Prather, M. J., Pyle, J. A., Rast, S., Rodriguez, J. M., Sanderson, M. G., Savage, N. H., Shindell, D. T., Strahan, S. E., Sudo, K., and Szopa, S.: (2006), Multimodel ensemble simulations of present-day and near-future tropospheric ozone, J. Geophys. Res., 111, D08301, doi:10.1029/2005JD006338, 2006.

Stohl, A.: Computation, accuracy and applications of trajectories a review and bibliography, Atmos. Environ., 32, 947-966, 1998.

Stohl, A. and Seibert, P.: Accuracy of trajectories as determined from the conservation of meteorological tracers, Q. J. Roy. Meteor. Soc., 124, 1465-1484, doi:10.1002/qj.49712454907, 1998.

Stohl, A., James, P., Forster, C., Spichtinger, N., Marenco, A., Thouret, V., and Smit, H. G. J.: An extension of Measurement of Ozone and Water Vapour by Airbus In-service Aircraft (MOZAIC) ozone climatologies using trajectory statistics, J. Geophys. Res., 106, 27757-27768, doi:10.1029/2001JD000749, 2001.

Stübi, R., Levrat, G., Hoegger, B., Viatte, P., Staehelin, J., and Schmidlin, F. J.: In-flight comparison of Brewer-Mast and electrochemical concentration cell ozonesondes, J. Geophys. Res., 113, D13302, doi:10.1029/2007JD009091, 2008.

Sutton, R. T., Maclean, H., Swinbank, R., O'Neill, A., and Taylor, F. W.: High-Resolution Stratospheric Tracer Fields Estimated from Satellite Observations Using Lagrangian Trajectory Calculations, J. Atmos. Sci., 51, 2995-3005, 1994.

Tarasick, D. W., Davies, J., Anlauf, K., Watt, M., Steinbrecht, W., and Claude, H. J.: Laboratory investigations of the response of Brewer-Mast sondes to tropospheric ozone, J. Geophys. Res., 107, 4308, doi:10.1029/2001JD001167, 2002.

Tarasick, D. W., Fioletov, V. E., Wardle, D. I., Kerr, J. B., and Davies, J.: Changes in the vertical distribution of ozone over Canada from ozonesondes: 1980-2001, J. Geophys. Res., 110, D02304, doi:10.1029/2004JD004643, 2005.

Tarasick, D. W., Jin, J. J., Fioletov, V. E., Liu, G., Thompson, A. M., Oltmans, S. J., Liu, J., Sioris, C. E., Liu, X., Cooper, O. R., Dann, T., and Thouret, V.: High-resolution tropospheric ozone fields for INTEX and ARCTAS from IONS ozonesondes, J. Geophys. Res., 115, D20301, doi:10.1029/2009JD012918, 2010.
Tilmes, S., Lamarque, J.-F., Emmons, L. K., Conley, A., Schultz, M. G., Saunois, M., Thouret, V., Thompson, A. M., Oltmans, S. J., Johnson, B., and Tarasick, D.: Technical Note: Ozonesonde climatology between 1995 and 2011: description, evaluation and applications, Atmos. Chem. Phys., 12, 74757497, doi:10.5194/acp-12-7475-2012, 2012.

von Kuhlmann, R., Lawrence, M. G., Crutzen, P. J., and Rasch, P. $\mathrm{J}$.: A model for studies of tropospheric ozone and nonmethane hydrocarbons: Model description and ozone results, J. Geophys. Res., 108, 4294, doi:10.1029/2002JD002893, 2003.

Worden, H. M., Logan, J. A., Worden, J. R., Beer, R., Bowman, K., Clough, S. A., Eldering, A., Fisher, B. M., Gunson, M. R., Herman, R. L., Kulawik, S. S., Lampel, M. C., Luo, M., Megretskaia, I. A., Osterman, G. B., and Shephard, M. W.: Comparisons of Tropospheric Emission Spectrometer (TES) ozone profiles to ozonesondes: Methods and initial results, J. Geophys. Res., 112, D03309, doi:10.1029/2006JD007258, 2007a.

Worden, J., Liu, X., Bowman, K., Chance, K., Beer, R., Eldering, A., Gunson, M., and Worden, H.: Improved tropospheric ozone profile retrievals using OMI and TES radiances, Geophys. Res. Lett., 34, L01809, doi:10.1029/2006GL027806, 2007 b.

World Climate Research Programme, SPARC/IOC/GAW Assessment of Trends in the Vertical Distribution of Ozone, Stratospheric Processes and Their Role in Climate, World Meteorol. Organ. Global Ozone Res. Monit. Proj. Rep, 43, Geneva, Switzerland, 1998.

World Meteorological Organization, International meteorological vocabulary, WMO Rep. 182, World Meteorol. Org., Geneva, Switzerland, 1992.

Young, P. J., Archibald, A. T., Bowman, K. W., Lamarque, J.-F., Naik, V., Stevenson, D. S., Tilmes, S., Voulgarakis, A., Wild, O., Bergmann, D., Cameron-Smith, P., Cionni, I., Collins, W. J., Dalsøren, S. B., Doherty, R. M., Eyring, V., Faluvegi, G., Horowitz, L. W., Josse, B., Lee, Y. H., MacKenzie, I. A., Nagashima, T., Plummer, D. A., Righi, M., Rumbold, S. T., Skeie, R. B., Shindell, D. T., Strode, S. A., Sudo, K., Szopa, S., and Zeng, G.: Preindustrial to end 21 st century projections of tropospheric ozone from the Atmospheric Chemistry and Climate Model Intercomparison Project (ACCMIP), Atmos. Chem. Phys., 13, 20632090, doi:10.5194/acp-13-2063-2013, 2013.

Ziemke, J. R., Chandra, S., Duncan, B. N., Froidevaux, L., Bhartia, P. K., Levelt, P. F., and Waters, J. W.: Tropospheric ozone determined from Aura OMI and MLS: Evaluation of measurements and comparison with the Global Modeling Initiative's Chemical Transport Model, J. Geophys. Res., 111, D19303, doi:10.1029/2006JD007089, 2006. 